Review Article

\title{
Transforming Growth Factor Beta Family: Insight into the Role of Growth Factors in Regulation of Fracture Healing Biology and Potential Clinical Applications
}

\author{
Lukasz A. Poniatowski, ${ }^{1}$ Piotr Wojdasiewicz, ${ }^{1,2,3}$ Robert Gasik, $^{2,3}$ and Dariusz Szukiewicz \\ ${ }^{1}$ Department of General and Experimental Pathology with Centre for Preclinical Research and Technology (CePT), \\ Second Faculty of Medicine, Medical University of Warsaw, Pawińskiego 3c, 02-106 Warsaw, Poland \\ ${ }^{2}$ Department of Rheumaorthopaedics, Institute of Rheumatology, Spartańska 1, 02-637 Warsaw, Poland \\ ${ }^{3}$ Department of Neuroorthopaedics and Neurology, Institute of Rheumatology, Spartańska 1, 02-637 Warsaw, Poland
}

Correspondence should be addressed to Dariusz Szukiewicz; dszukiewicz@hotmail.com

Received 4 September 2014; Accepted 9 November 2014

Academic Editor: Philip Stahel

Copyright (C) 2015 Łukasz A. Poniatowski et al. This is an open access article distributed under the Creative Commons Attribution License, which permits unrestricted use, distribution, and reproduction in any medium, provided the original work is properly cited.

\begin{abstract}
The transforming growth factor beta (TGF- $\beta$ ) family forms a group of three isoforms, TGF- $\beta 1$, TGF- $\beta 2$, and TGF- $\beta 3$, with their structure formed by interrelated dimeric polypeptide chains. Pleiotropic and redundant functions of the TGF- $\beta$ family concern control of numerous aspects and effects of cell functions, including proliferation, differentiation, and migration, in all tissues of the human body. Amongst many cytokines and growth factors, the TGF- $\beta$ family is considered a group playing one of numerous key roles in control of physiological phenomena concerning maintenance of metabolic homeostasis in the bone tissue. By breaking the continuity of bone tissue, a spread-over-time and complex bone healing process is initiated, considered a recapitulation of embryonic intracartilaginous ossification. This process is a cascade of local and systemic phenomena spread over time, involving whole cell lineages and various cytokines and growth factors. Numerous in vivo and in vitro studies in various models analysing cytokines and growth factors' involvement have shown that TGF- $\beta$ has a leading role in the fracture healing process. This paper sums up current knowledge on the basis of available literature concerning the role of the TGF- $\beta$ family in the fracture healing process.
\end{abstract}

\section{Introduction}

Disorders involving the musculoskeletal system are one of the most diversified groups of diseases [1]. They include congenital and acquired diseases directly affecting bones, joints, ligaments, and muscles, as well as disorders, in which this system is involved secondarily [2]. All musculoskeletal system disorders represent a continuous challenge to the society, considering their complex and often multifactor aetiology, varied course, and economic aspects, as well as a still present problem of implementing optimal surgical and nonsurgical treatment $[1,2]$. One of the most serious conditions encountered in the clinical practice is fractures, that is, breaking of the bone continuity caused by an injury or other reasons, including osteoporosis, cancer, or other systemic diseases $[2,3]$. The bone damage can also be accompanied by soft tissues damage of different extent, also affecting crucial structures such as vessels and nerves [4]. Any tissue damage, caused by the injury or the surgery itself, involves not only a local immunological response and inflammation, but also a systemic immunological response related to inflow, migration, and proliferation of a broad spectrum of cells [5-9]. Cytokines are molecules responsible for controlling intracellular communication and directing the immunological reaction [10]. This group of low-molecular glycoproteins forms a "cytokine network" in the body [11, 12]. Amongst cytokines identified and described so far, a group of growth factors (GF) can also be distinguished, whose effects in certain situations can also be viewed in a context of a "growth factor network" [13]. The transforming growth factor beta 


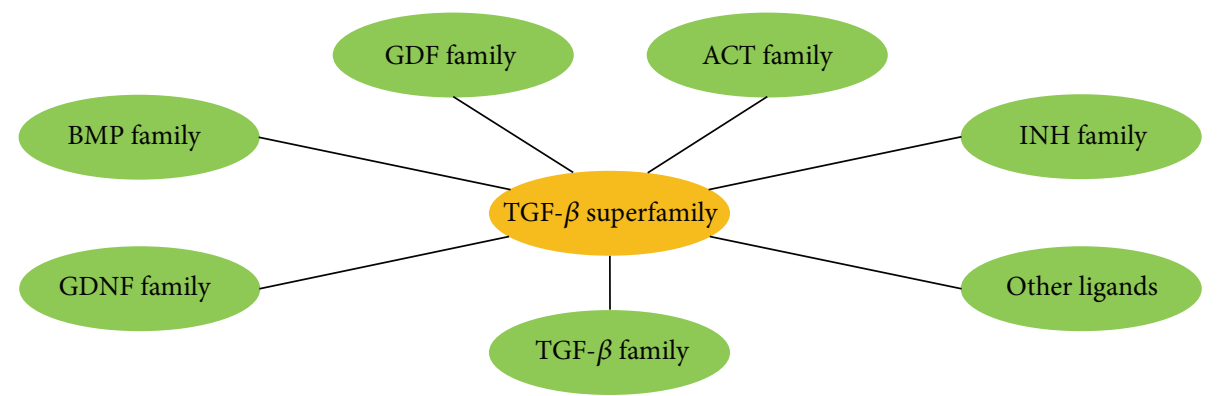

FIGURE 1: A schematic representation of TGF- $\beta$ superfamily. TGF- $\beta$ : transforming growth factor beta; GDF: growth and differentiation factor; ACT: activin; INH: inhibin; other ligands include Müllerian inhibiting substance (MIS) or anti-Müllerian hormone (AMH), leftright determination factor (Lefty), and nodal growth differentiation factor (Nodal); GDNF: glial-derived neurotrophic factors; BMPs: bone morphogenetic proteins.

(TGF- $\beta$ ) superfamily requires a particular attention. The TGF- $\beta$ superfamily is a large and continuously expanded group of regulatory polypeptides, including a model transforming growth factor beta family and other families, such as bone morphogenetic proteins (BMPs), growth and differentiation factors (GDFs), activins (ACTs), inhibins (INHs), and glial-derived neurotrophic factors (GDNFs), as well as some proteins not included in the above families, such as Müllerian inhibiting substance (MIS), also known as anti-Müllerian hormone (AMH), left-right determination factor (Lefty), and nodal growth differentiation factor (Nodal) [14] (Figure 1).

A number of molecules in the TGF- $\beta$ superfamily have crucial roles in tissue development and differentiation in vertebrates, control of the immunological response, and healing of tissues [14-17]. Similarly to all growth factors, the model TGF- $\beta$ family is characterised by its pleiotropic and redundant effects, controlling its effects in most body tissues in autocrinic, paracrinic, and endocrinic ways [18, 19]. Polypeptides in the TGF- $\beta$ family have an important role in control of cell activity and metabolism in bone and cartilage tissues throughout the ontogenetic human development $[20,21]$. These attributes of the TGF- $\beta$ family are also observed during the bone healing process, considered to be a recapitulation of embryonic intracartilaginous ossification $[22,23]$. Amongst many cytokines and growth factors, the TGF- $\beta$ family is considered to be a group playing one of numerous key functions in control of physiological phenomena during the bone healing process $[24,25]$. An increased expression of ligands from the TGF- $\beta$ family is observed both within haematoma and in serum of patients with long bone fractures [26,27]. A broad action profile of polypeptides from the TGF- $\beta$ family includes their effect on proliferation and differentiation of mesenchymal stem cells (MSCs), production of extracellular substance in bone and cartilage tissues, and a chemoattracting effect on a broad spectrum of cells involved in the bone healing process and the associated inflammatory response $[28,29]$. In this review, we will discuss a structure of compounds in the TGF- $\beta$ family and their relevant receptor complexes, ligand-receptor interactions, and resultant intracellular signal transmission cascades, as well as types of cellular effects in terms of their role in mechanisms and phenomena occurring during individual bone healing stages.

\section{Structural Organization of the TGF- $\beta$ Family}

2.1. TGF- $\beta$ Family Overview. For the first time, polypeptides in the TGF- $\beta$ family were isolated by de Larco and Todaro at the end of the 1970s as a group of compounds called by them the sarcoma growth factor (SGF): the compounds able to cause malignant transformation of rat kidney fibroblasts $[30,31]$. Only further studies showed that SGF is a mixture of two different compounds characterised by different properties, called transforming growth factor beta (TGF$\beta$ ) and transforming growth factor alpha (TGF- $\alpha$ ) from the epidermal growth factor (EGF) family, respectively [31, 32]. Currently, the TGF- $\beta$ family includes its three isoforms TGF$\beta 1$, TGF- $\beta 2$, and TGF- $\beta 3$. Each of the isoforms found in humans is coded by genes having different locations in various chromosomes: in a long arm of the chromosome 19 (19q13.1) for TGF- $\beta 1$, a long arm of the chromosome 1 (1q41) for TGF- $\beta 2$, and a long arm of the chromosome 14 (14q24) for TGF- $\beta 3$, respectively [33-35]. When analysing their primary structure, polypeptides from the TGF- $\beta$ family form a highly homologous group of compounds, where mature forms of TGF- $\beta 1$ and TGF- $\beta 2$ are characterised by $71.4 \%$ compliance in their amino acid sequences, while TGF- $\beta 3$ shares with TGF- $\beta 1$ and TGF- $\beta 276 \%$ and $80 \%$ of its amino acid sequence, respectively $[36,37]$. A prototype TGF- $\beta 1$ compound, the isoform most commonly found in human tissues, in its active form after a complete posttranslation processing is a homodimer consisting of two polypeptide chains, each containing 112 amino acid residues, connected by a disulphide bond and forming a complex of a total molecular weight of $25 \mathrm{kDa}$ $[38,39]$.

\subsection{TGF- $\beta$ Family Ligands Synthesis and Posttranslational} Modification. Synthesis, posttranslational modification, secretion, and control of later activation of polypeptides from the TGF- $\beta$ family form a complex and multistage process controlled by several enzymes and proteins (Figure 2).

Polypeptides from the TGF- $\beta$ family are initially synthesised as pre-pro-TGF- $\beta$, a monomer of a molecular weight of ca. $55 \mathrm{kDa}$ and consisting of 390 amino acid residues in total, including N-terminal signal peptide (SP) of 29 amino 


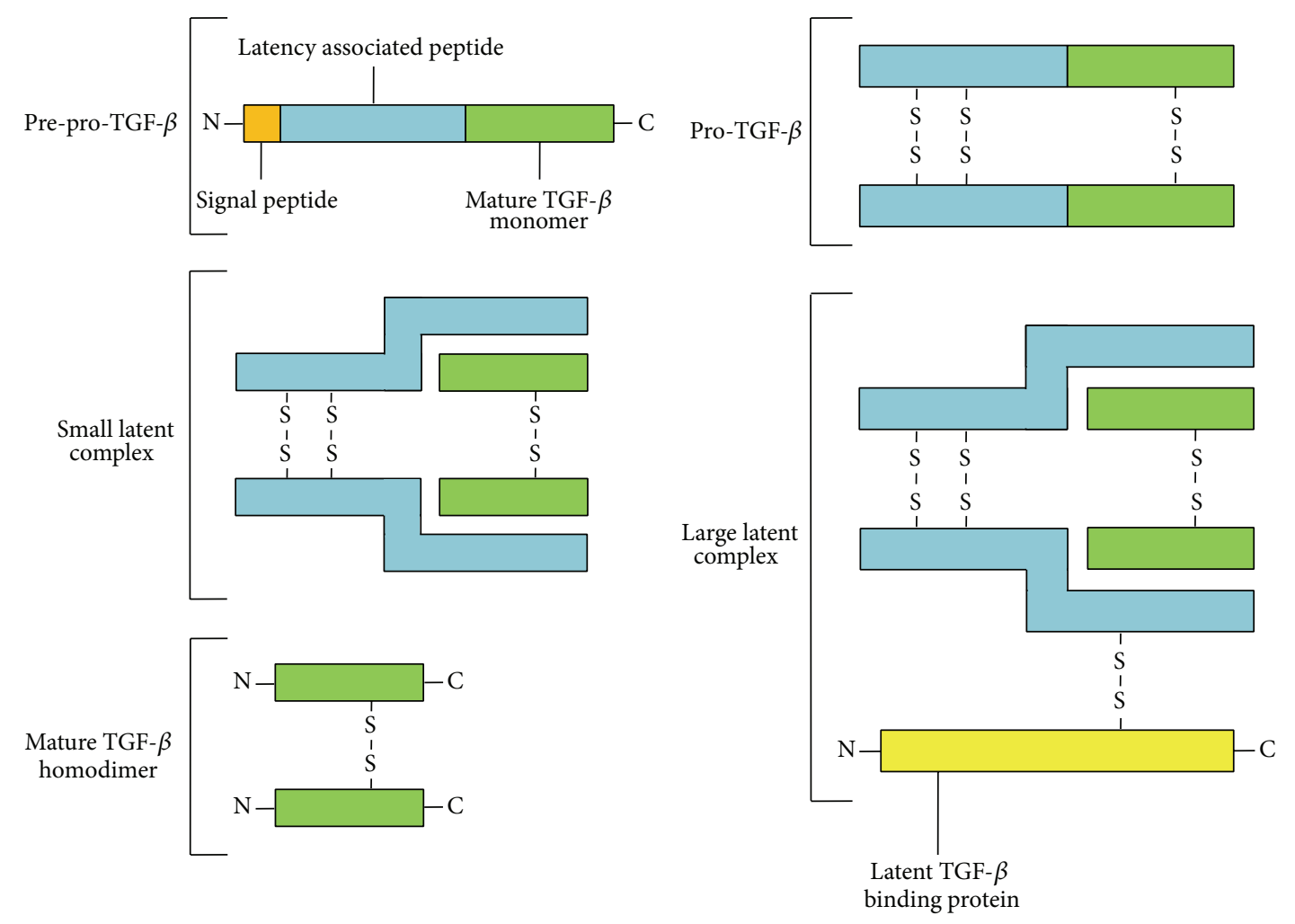

Figure 2: A schematic representation of TGF- $\beta$ different forms occurring during synthesis, secretion, and activation.

acids, a proregion of 249 amino acids called latency associated peptide (LAP), and a C-terminal sequence of 112 amino acids forming the actual active form of TGF- $\beta$ after relevant modifications [40, 41]. Further stages involve proteolysis and SP removal, as well as dimerisation of two monomers with three disulphide bonds [42]. Forming of bonds is catalysed by an enzyme, disulfide isomerase (PDI), between cysteine (Cys) residues in positions 223,225 , and 356 , and this way the pro-TGF $\beta$ homodimer is created of a molecular weight of ca. $110 \mathrm{kDa}$ consisting of two LAP chains and two chains of mature TGF- $\beta[43,44]$. Then, created pro-TGF$\beta$ undergoes proteolysis by paired basic amino acid cleaving enzyme (furin, PACE) which is membrane-associated calcium-dependent serine endoprotease, abundant in the Golgi apparatus, and in consequence two connected LAP chains are separated from two connected TGF- $\beta$ chains by cutting a bond between 278 and 279 amino acid residues $[45,46]$. The proteolysis results in creation of a small latent TGF- $\beta$ complex (SLC), in which connection between two LAP chains and two TGF- $\beta$ chains is maintained by noncovalent bonds, despite separation of polypeptide chains [47, 48]. Furthermore, LAP chains by changes in conformation and noncovalent bonds form a specific type of protection (chaperone-like activity), maintaining TGF- $\beta$ in its inactive form and preventing its interaction with a receptor [49]. SLC is then connected with a disulphide bond formed between cysteine residue in a 33 locations and a cysteine residue in the third of four cysteine-rich domains (8-Cys3) of the latent TGF- $\beta$ binding protein (LTBP) of a molecular weight of $120-160 \mathrm{kDa}$, characterised, apart from its four cysteinerich domains, by eighteen EGF-like domains; the resultant protein is called the large latent TGF- $\beta 1$ complex (LLC) [50-53]. The next stage involves LCC secretion from a cell, and it is worth noting that LCC secretion is significantly faster than SLC secretion, and SLC not bound to LTBP is stopped at the cis pole of the Golgi apparatus $[54,55]$. After secretion, parts of the complex interact with extracellular matrix (ECM) components, where C-terminal end of the LGBP protein interacts with $\mathrm{N}$-terminal end of fibrylin1, while its $\mathrm{N}$-terminal end can interact with other ECM proteins, including fibronectin (FN), and this can result in its anchoring with forming of a covalent bond, with participation of a transglutaminase enzyme (TG) [56-60]. LCC anchored this way in ECM components is a form without biological activity [61]. Apart from its interactions with fibylin-1 and fibronectin, LCC can also show affinity through integrin-binding sites (RGD) in the C-terminal end of the LAP chain to integrins, glycoproteins included in adhesive proteins of heterodimeric structure consisting of two noncovalently bound subunits, one of eighteen $\alpha$ and one of eight $\beta$ subunits [62-64]. LCC bond with integrins also allows releasing and activating the mature TGF- $\beta$ form by changing formation of the whole complex without a need for proteolytic digestion [65-67]. The main route for TGF- $\beta$ release from the LCC complex is related to presence and effect of numerous molecules, mainly including proteases such as plasmin, matrix metalloproteinase 2 (MMP2, gelatinase A), matrix metalloproteinase 9 (MMP9, gelatinase B), BMP-1, 


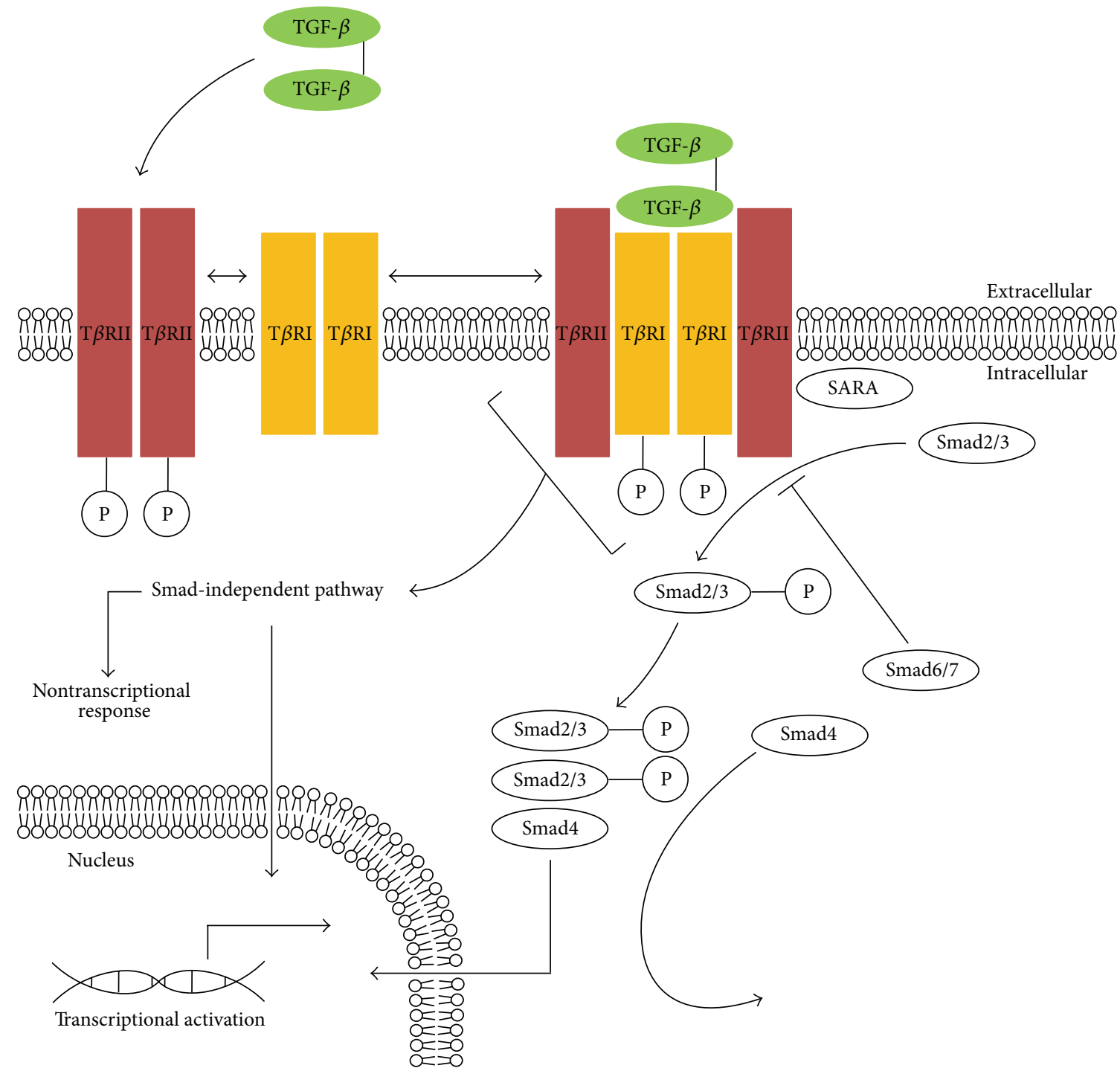

FIGURE 3: TGF- $\beta$ associated intracellular canonical and noncanonical signaling pathways. Perpendicular line indicates an inhibitory effect; TGF- $\beta$ : transforming growth factor beta; T $\beta$ RI: transforming growth factor, beta receptor type I; T $\beta$ RII: transforming growth factor, beta receptor type II; P: phosphate group; SARA: Smad anchor for receptor activation; Smad2/3: Smad family member 2/3; Smad6/7: Smad family member 6/7; Smad4: Smad family member 4.

and others, such as thrombospondin 1 (THBS1), retinoic acid, and fibroblast growth factor 2 (FGF2), as well as reactive oxygen species (ROS); low ECM pH can also influence TGF$\beta$ activity [68-74].

\subsection{TGF- $\beta$ Family Receptors and Signalling Pathways}

2.3.1. TGF- $\beta$ Family Receptors Characteristic and Regulation of Activity. Biological effects of homodimers, including TGF$\beta 1$, TGF- $\beta 2$, and TGF- $\beta 3$, are visible in activation of similar signalling pathways and similar cellular effects $[75,76]$ (Figure 3). After TGF- $\beta$ release from ECM, it interacts with a receptor complex forming a heterotetrameric combination containing two of each of type I (T $\beta$ RI, TGFBR1) and type II (T $\beta$ RII, TGFBR2) subunits [76-78].
Both subunits, $\mathrm{T} \beta \mathrm{RI}$ and $\mathrm{T} \beta \mathrm{RII}$, are transmembrane glycoproteins penetrating through the whole cell membrane thickness, so it is possible to distinguish their three main sections, including an $\mathrm{N}$-terminal, ligand-binding extracellular part, a transmembrane part, and a C-terminal, intracellular part containing a domain with serine/threonine protein kinase activity $[79,80]$. T $\beta R I$ is a product of a gene located in a long arm of the chromosome 9 (9q22) and consists of 503 amino acid residues of a total molecular weight of $53 \mathrm{kDa}$ [81-84]. The N-terminal extracellular part is located between 1 and 126 amino acid residues, the transmembrane part is located between 126 and 146 amino acid residues, and the C-terminal intracellular part is located between 146 and 503 amino acid residues $[83,84]$. In the intracellular part, in the region between 175 and 205 amino acid residues, there is a 
so-called GS domain (TTSGSGSG), a region rich in repeated serine (Ser) and glycine (Gly) residues [83-85]. T $\beta$ RII is a product of a gene located in a short arm of the chromosome 3 (3p22) and is larger than T $\beta R I$, as it consists of 567 amino acid residues of a total molecular weight of $75 \mathrm{kDa}[84,86-88]$. The $\mathrm{N}$-terminal extracellular part is located between 1 and 166 amino acid residues, the transmembrane part is located between 166 and 187 amino acid residues, and the C-terminal intracellular part is located between 187 and 567 amino acid residues $[86,89]$. In its intracellular part, T $\beta$ RII does not contain a GS domain, and its region with serine/threonine protein kinase activity shows a $41 \%$ compliance in its amino acid sequence to the domain in T $\beta$ RI $[79,85]$. A precondition for signal transduction into a cell is correct formation of a heterotetrameric receptor complex, and in particular intracellular domains with serine/threonine protein kinase activity must move closer in correct space conditions [90, 91]. First, TGF- $\beta$ moves closer to T $\beta$ RII subunits which, being constitutively active, undergo autophosphorylation [91-93]. The next step is phosphorylation of the GS domain forming a part of T $\beta$ RI receptor and mutual incorporation of two T $\beta$ RI subunits and two T $\beta$ RII subunits, resulting in formation of a complex consisting of a TGF- $\beta$ ligand and a receptor heterotetramer able to transmit the signal further into the cell [91]. Besides T $\beta$ RI and T $\beta$ RII, also a type III (T $\beta$ RIII, TGFBR3, betaglycan) receptor can be distinguished, anchored in cell membrane with a highly glycosylated proteoglycan, of a molecular weight of $250-350 \mathrm{kDa}$ [94-96]. $\mathrm{T} \beta \mathrm{RIII}$ is not a typical receptor able to transmit signal because it does not contain a domain with serine/threonine activity but has a coreceptor function, able to present TGF- $\beta$ to a complex consisting of T $\beta$ RI and T $\beta$ RII units and, indirectly, to modify its activity in the extracellular space $[97,98]$. It has also been observed that endoglin (ENG, CD105), a homodimeric glycoprotein of a molecular weight of ca. 180$190 \mathrm{kDa}$ found on cell membrane surface, has properties similar to T $\beta$ RIII [99-101]. Endoglin also contains an RGD domain and shows affinity to TGF- $\beta 1$ and TGF- $\beta 3$ but not to TGF- $\beta 2[100,101]$. On the other hand, T $\beta$ RIII shows affinity to all three TGF- $\beta$ forms and the highest to TGF- $\beta 2$ [102]. Durability of the heterotetrameric subunit combination with the ligand is a precondition for the signal transmission into the cell [103]. Degradation of cell membrane receptors may occur in proteasome or by lysis in a lysosome [103]. T $\beta$ RI receptor ubiquitination is catalysed by ubiquitin-activating enzyme (E1 enzyme), ubiquitin-conjugating enzyme (E2 enzyme), and ubiquitin ligase (E3 enzyme) such as Smurf1 and Smurf2 and additionally requires presence of adapter protein Smad family member 7 (Smad7), a member of the inhibitor Smad (I-Smad) subclass [104-106], whereas lysosomal degradation does not always require ubiquitination [107]. Receptor complexes and TGF- $\beta$ ligand-bound receptor complexes are also subject to constitutive control related to their internalisation on the clathrin-dependent or lipid-raftdependent endocytic pathway, and this ensures their correct physiological response, activity, and distribution on a cell surface [108-110].
2.3.2. Intracellular TGF- $\beta$ Canonical and Noncanonical Signalling Pathways. Intracellular signal transduction is conducted through cytoplasmic proteins, belonging to transcription factors from the Smad family [111, 112]. Currently, three Smad protein classes are distinguished, namely, receptorregulated Smads (R-Smad) including Smad1, Smad2, Smad3, Smad5, and Smad8, common-mediator Smad (Co-Smad) including Smad4, and inhibitory Smads (I-Smad) including Smad6 and Smad7 [113]. In their structure, R-Smad and CoSmad have similar domain structure consisting of highly conservative Mad homology 1 (MH1) at the $\mathrm{N}$-terminal and Mad homology $2(\mathrm{MH} 2)$ at the $\mathrm{C}$-terminal, connected by a binding protein rich in proline (Pro) residues forming tridimensional globular structures $[114,115]$. The $\mathrm{MH1}$ domain is responsible for binding with a DNA strand, promoting transcription activity, and the $\mathrm{MH} 2$ domain is responsible for interactions with other proteins and oligomerisation of Smad proteins $[114,116]$. Contrary to two other classes, I-Smad contains only one conservative domain MH2 [115]. In intracellular signal transmission via a canonical signalling pathway, the signal is propagated from the formed TGF- $\beta$ ligand-bound receptor heterotetramer to the nucleus via proteins from the Smad family [117]. The activated receptor subunit T $\beta R I$ initiates, crucial for signal transmission, phosphorylation of an R-Smad protein (Smad2 and Smad3) bound through the zinc double finger (FYVE domain) protein Smad anchor for receptor activation (SARA) [118]. SARA is a membraneassociated intracellular protein able to recruit the activated $\mathrm{T} \beta \mathrm{RI}$ subunit and proteins from the Smad family dissociating from SARA following phosphorylation [118]. After phosphorylation of the C-terminal SSXS motif, a part of MH2 $\mathrm{R}$-Smad proteins, Co-Smad is recruited and a heterotrimer is formed consisting of two phosphorylated R-Smads and CoSmad [111]. This complex is transported to the nucleus, and its correct translocation is possible because of a lysine- (Lys-) rich nuclear localization-like (NLS-like) sequence forming a part of the MH1 R-Smad domain and Co-Smad and facilitates interaction with importin- $\alpha$ and importin- $\beta[119,120]$. In the nucleus, the R-Smad/Co-Smad complex connects with other nuclear cofactor proteins, and the gene transcription process is initiated [121]. I-Smad proteins are responsible for negative signal transmission by competing with R-Smad proteins in binding with the receptor or Co-Smad and promote selection of receptors for proteolytic degradation [122-124]. Apart from intracellular signal transmission by Smad proteins, the TGF- $\beta$ receptor complex can also transmit signal via a noncanonical pathway (Smad-independent pathway), that is, by other intracellular signal transmission pathways $[125,126]$. The possible signal transmission pathways to the nucleus include mitogen-activated protein kinases (MAPK), such as extracellular-signal-regulated kinases 1/2 (ERK1/2), c-Jun Nterminal kinase (JNK), p38, and phosphatidylinositol-4,5bisphosphate 3-kinase (PI3K), AKT/PKB pathway, as well as small GTP-binding proteins (Ras, RhoA, Racl, CDC42, and $\mathrm{mTOR}$ ) and protein tyrosine kinases (PTK2, Src, and $\mathrm{Abl}$ ), and, furthermore, NF- $\kappa \mathrm{B}$ pathway and $\mathrm{Wnt} / \beta$-catenin pathway [127-134]. 


\section{Potential Role of TGF- $\beta$ Family in Fracture Healing}

3.1. Basic Principles of Fracture Healing and the Application of These Principles in Crosstalk between Cells and Growth Factors. Bone and cartilage tissues represent a special type of a dynamic microenvironment subject to constant, orderly, and lasting whole life reconstruction at a cellular level $[135,136]$. A whole range of local and systemic factors are involved in maintaining metabolic homeostasis of the bone tissue so it can perform its functions [136]. When the continuity of the bone tissue is disrupted, a number of factors are activated, including a broad profile of cells and intensified gene transcription [137-139]. The whole cascade of events starts immediately with an injury and causes both local and systemic effects [7-9]. Physiological interactions and phenomena occurring during three main phases of bone healing, including an inflammatory phase, a reparative phase, and a remodelling phase, finally restore correct architecture and function of the bone tissue within 6-8 weeks [140]. During these phases, there is an interaction between various cells, whose behaviour is regulated by various cytokines, growth factors, and their dedicated receptor complexes, whose expression, participation, and function vary depending on the healing stage, and, furthermore, depends on a fracture type and kind, operative and nonoperative treatment methods applied, comorbidities, and patient's adherence to recommendations [27, 140-143]. Four main components can be distinguished in the fracture zone: periosteum, cortex, bone marrow, and surrounding soft tissues involved in repair processes; there are also differences in presence and number of individual cell types, cytokines, and growth factors in each of these components throughout the bone healing process $[141,143,144]$. The most important compounds belonging to proinflammatory cytokines, growth and differentiation factors, and angiogenic factors include the TGF- $\beta$ family, FGF1, FGF2, platelet-derived growth factor (PDGF), insulin-like growth factor 1 (IGF-1), insulin-like growth factor 2 (IGF-2), BMP family, osteonectin (ON, SPARC), osteocalcin (BGLAP), osteopontin (OPN, SPP1), fibronectin, interleukin 1 (IL-1), interleukin 6 (IL-6), TNF- $\alpha$, granulocyte-macrophage colony-stimulating factor (GMCSF), macrophage colony-stimulating factor (M-CSF, CSF1), and vascular endothelial growth factor (VEGF) [144-148]. Numerous in vivo and in vitro studies on various models analysing cytokines and growth factors' involvement have shown that TGF- $\beta$ has a leading role in the fracture healing process $[24,25,149]$. The analysis of the TGF- $\beta$ family multidirectional effect is inseparably connected with the whole bone healing process and possible clinical application in modifying individual bone healing phases to achieve better treatment effects.

\subsection{Expression and Localization of TGF- $\beta$ Family during Fracture Healing}

3.2.1. Local Expression and Distribution of TGF- $\beta$ in Fracture Site. Increased TGF- $\beta$ expression, effect, and tissue distribution start with breaking of bone tissue continuity at the inflammatory phase onset, exhibiting increased local and systemic concentration [150]. TGF- $\beta$ presence in the extracellular space with the forming haematoma can be determined in the periosteum region within $24 \mathrm{~h}$ from the fracture, and one of its main sources is thrombocytes, and specifically $\alpha$ granules representing ca. $10 \%$ of their volume, as well as immune system cells such as monocytes, macrophages, and T-cells and cells directly present in the fracture region, including osteocytes, chondrocytes, and endothelial cells [150-152]. Several days after the fracture, the reparative phase is initiated, with its main stages being the intramembranous ossification phase and the endochondral ossification phase, overlapping in time. TGF- $\beta$ presence is most pronounced during this phase within organising callus and cells found in it, such as MSCs, osteoblasts, osteocytes, chondroblasts, and chondrocytes $[152,153]$. An analysis of Joyce et al. study results shows that presence of TGF- $\beta$ RNA within the soft callus gradually increases from the 7 th to 14 th day of the fracture and then decreases from the 14th to 17th day of the fracture, while in the subperiosteal bone formation TGF- $\beta$ RNA is most abundant in the 3rd to 5th day of the fracture and then it drops and reaches plateau from the 7th to 11th day of the fracture, to increase again in a period from the 11th to 15th day of the fracture; these results were additionally confirmed by observations of Bourque et al. [152, 153]. A study conducted by Matsumoto et al. showed that the increased TGF- $\beta$ level within the callus is found between the 7 th and 14 th day of the fracture [154]. Si et al. showed that the increased TGF- $\beta$ level occurs during the endochondral ossification phase [155]. The study conducted by Cho et al., concerning presence of RNA for each TGF- $\beta$ isoform, showed that TGF- $\beta 1$ RNA is intensively expressed during the whole healing process, while TGF- $\beta 2$ RNA and TGF- $\beta 3$ RNA levels are the highest on the 7 th day of the fracture [156]. Meyer Jr. et al. recorded the highest TGF- $\beta$ RNA levels within callus in a period from the 7 th to 14 th day of the fracture [157]. In another study, Wildemann et al. found that the TGF- $\beta 1$ RNA level increases constitutively within callus from the 5th to 15th day of the fracture [158]. Analysing available literature and results of studies conducted in animal models concerning TGF- $\beta$ presence and considering also slightly different methodology of each study, it can be said that the highest callus levels at the fraction site are found directly after the fracture and on onset and duration of the reparative phase; moreover, Andrew et al. found that the animal model sufficiently reflects phenomena occurring after fracture in humans [152-159]. Not only does increased expression of TGF- $\beta$ ligands occur in callus, but it is accompanied by increased expression of $\mathrm{T} \beta \mathrm{RI}$ and $\mathrm{T} \beta \mathrm{RII}$ receptors and intracellular proteins such as Smad 2 and Smad3, directly involved in signal transduction to the nucleus and whose increased presence is correlated with increased TGF- $\beta$ levels $[160,161]$.

3.2.2. Systemic Expression and Concentration of TGF- $\beta$. Apart from its local expression at the fracture site, TGF- $\beta$ is also distributed systemically, which is reflected by its increased serum levels in circulating blood. Levels of circulating TGF$\beta$ are lower than those found at the fracture site, while its level is significantly increased versus serum collected from 
healthy control groups $[26,162]$. It was observed that the TGF- $\beta$ serum level increases gradually during the first two weeks reaching its maximum level on the 14th day of the fracture, and then, during the next 24 weeks, it decreases slowly reaching levels noted in patients from control groups $[26,162,163]$. Also a significant difference was observed between TGF- $\beta$ serum levels in patients with correct bone healing and groups of patients with delayed or nonunion fracture healing $[26,162,163]$. One of the reasons, which was correlated with decreased TGF- $\beta$ levels and delayed union, is smoking of cigarettes, where serum TGF- $\beta$ levels in patients with fractures were significantly lower in the smoking group versus the nonsmoking patients [164-166]. Li et al. also presented a hypothesis that increased serum TGF- $\beta$ levels in patients with close fractures may predispose to tuberculosis (MTB, TB) development [167].

3.3. Multiple Actions of TGF- $\beta$ on Fracture Site Microenvironment. TGF- $\beta$ and BMP families belong to the best known groups of compounds having the effect on the bone tissue [168]. The bone tissue is the largest TGF- $\beta$ reservoir in the body, and it contains more than $200 \mu \mathrm{g} / \mathrm{kg}$ of wet weight, whereas thrombocytes represent the most concentrated source of TGF- $\beta$ around $20 \mathrm{mg} / \mathrm{kg}$ of wet weight $[169,170]$. Almost every cell in a body is able to synthesise and respond to TGF- $\beta$ ligands, and, in a case of cell lineages engaged in the bone healing process, this response also depends on differentiation degree of a relevant cell, presence of other cells, and an effect of other cytokines and growth factors. A moment when the bone tissue continuity is disrupted following an injury or osteotomy is also the moment when TGF- $\beta$ starts to fulfill its physiological role in the processes of proliferation, differentiation, and synthesis of cartilage and bone tissue, collectively known as the bone healing process (Figure 4). Cellular effects caused by TGF- $\beta$ attachment to cell surface can be viewed as specific connection between the inflammatory and the repair phases during fracture healing. The main sources of TGF- $\beta$ present during the bone healing process are practically all cells involved in that process, incoming blood platelets, and the surrounding ECM releasing TGF- $\beta$ following a mechanical injury causing tissue ischaemia and local change in $\mathrm{pH}$, facilitating release not only of TGF- $\beta$, but also of other growth factors, such as PDGF, VEGF, or BMP-2 $[171,172]$. Functionally, multidirectional TGF- $\beta$ effects are based on autocrine and paracrine signalling and, in the cellular aspect, on induction of ECM production and ossification, resulting in bone healing. One of the most important TGF- $\beta$ functions is its chemotactic ability, enabling recruitment of MSC, chondroprogenitor cells, osteoprogenitor cells, fibroblasts, and immune cells such as macrophages, monocytes, and T-cells [173-177]. At the same time, at early stages, TGF- $\beta$ inhibits activation, proliferation, and differentiation of osteoclasts and moreover induces their apoptosis and additionally promotes development of callus and prevents its premature resorption, as only during the remodelling phase TGF- $\beta$ becomes a regulator of its activity [178-181].

The TGF- $\beta$ effect on the cartilage tissue includes proliferation of precursors or immature chondrocytes and increased
ECM production in the cartilage [182]. For the bone tissue cells, TGF- $\beta$ plays a crucial role in their proliferation and differentiation in bone development and remodelling processes. TGF- $\beta$ controls proliferation and remodelling of osteoblasts both in vitro and in vivo, but the final result of that control also depends on the cell differentiation level and the surrounding environment. TGF- $\beta$ effect on young forms promotes their proliferation while inhibiting terminal differentiation $[183,184]$. It was also demonstrated that TGF$\beta$ can have a negative effect on osteocalcin and alkaline phosphatase (ALP) synthesis through osteoblasts [184, 185]. Other components also synthesised by cells of the cartilage and the bone tissues due to the TGF- $\beta$ effect include I, II, III, $\mathrm{V}, \mathrm{VI}$, and X collagen, fibronectin, osteopontin, osteonectin, thrombospondin, proteoglycans, and alkaline phosphatase $[138,186]$. Apart from secretion of components contributing to fracture healing, TGF- $\beta$ can also influence synthesis of other growth factors such as VEGF $[187,188]$. One of the most crucial components during bone healing process is redevelopment and restoration of microvasculature and microcirculation supplying oxygen and nutrients to the fracture site and creating another route for penetration by other cell types, penetrating the damaged site via blood vessels $[189,190]$. TGF- $\beta$ is also one of the angiogenic factors promoting development of new blood vessels, such as VEGF [191-194]. Full and comprehensive understanding of the TGF- $\beta$ role in the bone healing process still poses difficulties, as often it has different and opposite cellular effects depending on numerous factors, and full interpretation of studies conducted in different models is often insufficient to consider a given effect to be typical and always occurring with the same intensity. It should also be remembered that TGF- $\beta$ effects occur within a "growth factor network"; thus the synergistic effect is visible as a resultant cellular effect of all involved compounds.

\subsection{Potential Clinical Approach and Evaluation of Using TGF- $\beta$ in Fracture Healing}

3.4.1. Analysis of Several In Vivo Studies in Using TGF- $\beta$ to Enhance Bone Healing. The TGF- $\beta$ effect is continuously studied in various animal models to analyse possibilities for its use in the clinical therapies for fracture healing. Abundance and variability of methodologies in individual studies allow us to review only some of them; however, they ensure sufficient insight in the TGF- $\beta$ effect on the fracture healing process in an animal model in various conditions, involving both small and large animals. Joyce et al. performed subperiosteal injections of TGF- $\beta 1$ and TGF- $\beta 2$ to newly born rats, at doses ranging from 20 to $200 \mathrm{ng}$, and they observed that subperiosteal MSC starts to proliferate and differentiate at the injection site, inducing chondrogenesis and osteogenesis, and that TGF- $\beta 2$ has stronger effect than TGF- $\beta 1$ [195]. Results obtained by Joyce et al. were additionally confirmed by Sun et al. in a similar experimental model $[195,196]$. The experiment of Beck et al., concerning local administration of TGF- $\beta 1$ at doses ranging from 0.5 to $5 \mu \mathrm{g}$ to rabbits with skull defect, caused stimulation, recruitment, and proliferation of osteoblasts at the defect site resulting 


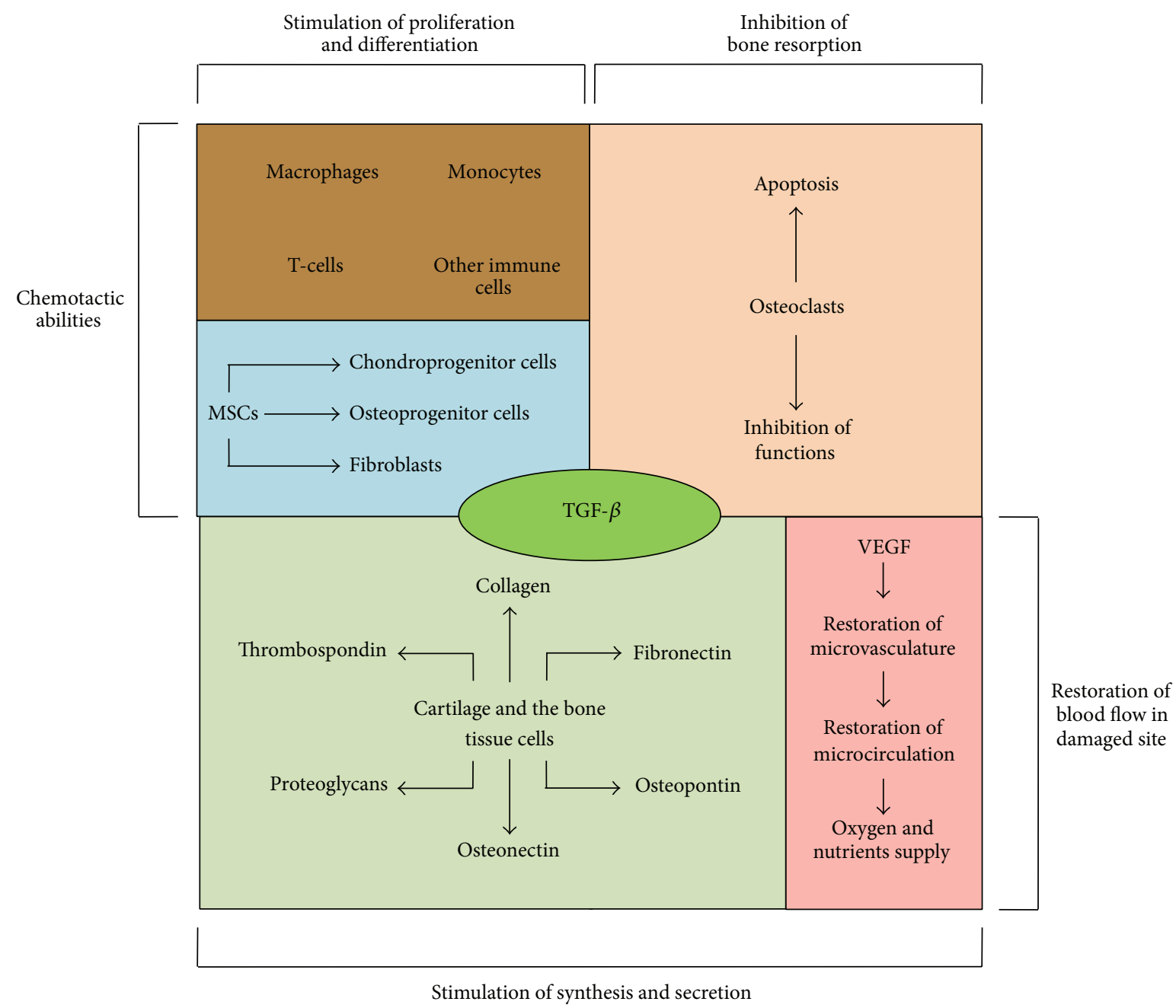

FIGURE 4: A schematic representation of TGF- $\beta$ interactions and effects in fracture site. TGF- $\beta$ : transforming growth factor beta; MSCs: mesenchymal stem cells; VEGF: vascular endothelial growth factor.

in healing [197]. Lind et al. administered TGF- $\beta 1$ and TGF$\beta 2$ with an osmotic minipump to adult rabbits with induced tibial bone fracture at a dose ranging from 1 to $10 \mu \mathrm{g}$ for six weeks, and after the end of the experiment they observed an increased mechanical strength in the fracture site and increased callus formation versus the control group not receiving TGF- $\beta$ [198]. Nielsen et al. in their study in the rat model with local administration of TGF- $\beta 1$ and TGF- $\beta 2$ at the level of 4 to $40 \mathrm{ng} /$ day to the fracture site in the tibial bone also observed an increased mechanical strength and callus formation at the fracture site, but only in the group receiving $40 \mathrm{ng} /$ day [199]. Critchlow et al. in their study in the rabbit model with local administration of TGF- $\beta 2$ at the level of 60 to $600 \mathrm{ng} /$ day to the fracture site in the tibial bone after 14 days of observations did not note an increased mechanical strength, and callus formation at the fracture site was minimal [200]. Heckman et al. in their study in the dog model, with no healing in the radius, applied a local implant of biodegradable polymer carrier containing BMP and TGF- $\beta 1$, depending on the group, and they found that only the carrier containing BMP had a positive effect on induction of bone growth, while the carrier containing 10 ng of TGF- $\beta$ did not give a significant effect on the bone, also when combined with BMP at various doses [201]. Schmidmaier et al. conducted a series of experiments in animal models on combined use of TGF$\beta$ and IGF- 1 and they demonstrated that both TGF- $\beta$ and IGF-1 have an advantageous effect on induction of improved bone healing, but when combined that effect is significantly magnified [148, 202-204]. The analysis of a broad spectrum of experiments conducted in animal models proves that local application of TGF- $\beta$ has a positive effect on speed and quality of resultant tissue and on completion of the bone healing process, and the final effect depends on whether TGF- $\beta$ was supplemented systemically or locally, the form of its supplementation, and whether it was present in combination with other growth factors or specific cell populations [205-209].

\subsubsection{Potential Clinical Use of TGF- $\beta$ to Enhance Human Bone} Healing. The analysis of available literature does not provide a clear answer to the following question: what are the effects of therapy involving TGF- $\beta$ on fracture healing in humans? Also effectiveness of platelet-rich plasma (PRP) administration, a 
blood derived preparation obtained from human blood with the increased platelet concentration, in fracture therapy, is still being studied and discussed [210-212]. PRP is a preparation containing supraphysiologic concentrations of growth factors including TGF- $\beta$; therefore, indirect interpretation can be attempted for the PRP effect on possible TGF- $\beta$ as a part of previous studies on bone healing [213]. So far, a number of randomised studies in humans on PRP effectiveness in fracture therapy are scarce [210-212]. Considering the methodological limitations, interpretation of individual available results cannot ensure a sufficient statistical value allowing a clear answer on PRP effectiveness in fracture healing. Dallari et al. analysed use of PRP and lyophilized bone chips in patients undergoing high tibial osteotomy; they obtained significant increase in quantity and quality of the bone tissue versus patients administered only lyophilized bone chips [214]. A similar study on PRP use during the high tibial osteotomy procedure was conducted by Peerbooms et al., where a positive effect of combined PRP and lyophilized bone chips use was not observed [215]. Apart from the two exemplary studies described above, also other studies on PRP applications were conducted, for example, during surgical fusion of other long bones, distraction osteosynthesis, and spine fusion, which also do not provide a clear answer concerning PRP use, and to a large extent this is also limited by methodology of these studies [216-220]. Unfortunately, an analysis of an isolated TGF- $\beta$ effect on the bone healing process in humans is currently impossible and is limited by the fact that so far no study was conducted concerning the effect of that growth factor on bone healing in humans.

3.4.3. Association between Polymorphisms in the TGF- $\beta$ Family Gene and Potential Susceptibility to Fracture. A broad spectrum of the TGF- $\beta$ family effects on the bone tissue is also visible in a direct effect on its metabolism, involving continuous resorption and synthesis of bone structures [181]. A disturbance of a subtle balance of these processes results in osteoporosis (OP), disease related to reduced bone mineral density (BMD) [221]. Significantly increased risk of fractures and possible complications during the fracture healing process are factors inseparably related to and correlated with osteoporosis [222, 223]. Many independent authors confirm that one of the main factors correlated with that disease development is a genetic factor manifested as presence of various mutations in the human genome, including genes encoding TGF- $\beta$ [224]. A polymorphism analysis for genes encoding TGF- $\beta$ in various populations proves that the polymorphisms most frequently mentioned by authors and potentially related to the increased OP and, indirectly, fracture risks are T29C, C509T, T869C, G915C, and 713-8delC polymorphisms and potentially C1348T and C788T [225-230].

\section{Conclusions and Perspective}

Bone healing is a complex process involving many types of cells and their interactions mediated by cytokines and growth factors. This paper presents a current collective analysis of the possible effect of one of the most important growth factor families, TGF- $\beta$, on the bone healing process. It presents specifications of TGF- $\beta$ ligands and their dedicated receptor complexes; the analysis also focused on the intracellular signal transduction pathway to the nucleus, with emphasis on possible anabolic cellular effects generated by TGF- $\beta$ during the bone healing process. Furthermore, on the basis of current global literature, a direct and an isolated TGF- $\beta$ effect was analysed in numerous animal models, including studies in large and small animals. The reliability of conclusions drawn on the basis of described and analysed numerous, multicenter, and independent studies by us can prove their applicability as a part of numerous methodologies. Also, a potential TGF- $\beta$ effect on bone healing was described, as an attempt of indirect interpretation of the PRP effect as a possible TGF- $\beta$ effect during previously conducted studies on fracture healing. Additionally, this paper notes TGF- $\beta$ gene polymorphisms which can imply an impaired biological function of this growth factor within the bone tissue, manifested as an increased predisposition to osteoporosis. In the light of collected information, the TGF- $\beta$ family can potentially be considered one of the most important factors stimulating and controlling the bone healing process. Although its role has been directly proven mainly in many animal models and cell cultures, it is considered that the observed TGF$\beta$ biological effect on bone and cartilage tissues correctly reflects its potential function in humans [159]. Currently, in the clinical practice, isolated TGF- $\beta$ is not used in treatment of fractures or bone healing disorders. Probably, it is caused by insufficient studies on possible complications and side effects, for example, related to potential development and exacerbation of cooccurring cancer, as well as to induction of the immunosuppressive condition [231-234]. Currently, PRP is used in treatment of bone healing disorders or other diseases of the musculoskeletal system; however, results of the studies concerning effectiveness of this therapy and its longterm effects are not unambiguous. This may indicate still not fully known mechanisms of growth factors effects as a part of a "growth factor network," meaning that it may be necessary to search for targeted fracture therapies with isolated TGF$\beta$, considering results of the studies in animal models. Many independent authors emphasise a need to conduct further, more detailed studies on the TGF- $\beta$ family participation, not only on effects or possible treatment of healing disorders, but also in terms of the widely understood regenerative medicine of other organs and tissues, to better learn and understand properties of this family [235-239]. It would enable and surely accelerate finding an answer to the question whether safe and targeted use of the therapy with isolated TGF- $\beta$ in humans is justified. However, earlier it will not be possible to answer questions concerning full knowledge about the TGF- $\beta$ role in the bone healing process.

\section{Conflict of Interests}

The authors declare that there is no conflict of interests regarding the publication of this paper. 


\section{References}

[1] A. D. Woolf, T. Vos, and L. March, "How to measure the impact of musculoskeletal conditions," Best Practice \& Research Clinical Rheumatology, vol. 24, no. 6, pp. 723-732, 2010.

[2] A. D. Woolf, P. Brooks, K. Akesson, and G. M. Mody, "Prevention of musculoskeletal conditions in the developing world," Best Practice \& Research Clinical Rheumatology, vol. 22, no. 4, pp. 759-772, 2008.

[3] C. B. de Mattos, O. Binitie, and J. P. Dormans, "Pathological fractures in children," Bone \& Joint Research, vol. 1, no. 10, pp. 272-280, 2012.

[4] F. Tull and J. Borrelli Jr., "Soft-tissue injury associated with closed fractures: evaluation and management," The Journal of the American Academy of Orthopaedic Surgeons, vol. 11, no. 6, pp. 431-438, 2003.

[5] H.-C. Pape, R. Marcucio, C. Humphrey, C. Colnot, M. Knobe, and E. J. Harvey, "Trauma-induced inflammation and fracture healing," Journal of Orthopaedic Trauma, vol. 24, no. 9, pp. 522$525,2010$.

[6] F. Hildebrand, H. C. Pape, and C. Krettek, "The importance of cytokines in the posttraumatic inflammatory reaction," Commons below Unfallchirurg, vol. 108, no. 10, pp. 793-803, 2005.

[7] R. Pfeifer, S. Darwiche, L. Kohut, T. R. Billiar, and H.-C. Pape, "Cumulative effects of bone and soft tissue injury on systemic inflammation: a pilot study," Clinical Orthopaedics and Related Research, vol. 471, no. 9, pp. 2815-2821, 2013.

[8] O. Bastian, J. Pillay, J. Alblas, L. Leenen, L. Koenderman, and T. Blokhuis, "Systemic inflammation and fracture healing," Journal of Leukocyte Biology, vol. 89, no. 5, pp. 669-673, 2011.

[9] P. Kobbe, Y. Vodovotz, D. J. Kaczorowski, T. R. Billiar, and H.C. Pape, "The role of fracture-associated soft tissue injury in the induction of systemic inflammation and remote organ dysfunction after bilateral femur fracture," Journal of Orthopaedic Trauma, vol. 22, no. 6, pp. 385-390, 2008.

[10] Y. Rochman, R. Spolski, and W. J. Leonard, "New insights into the regulation of T cells by $\gamma_{c}$ family cytokines," Nature Reviews Immunology, vol. 9, no. 7, pp. 480-490, 2009.

[11] F. R. Balkwill and F. Burke, “The cytokine network," Immunology Today, vol. 10, no. 9, pp. 299-304, 1989.

[12] Z. Frankenstein, U. Alon, and I. R. Cohen, "The immunebody cytokine network defines a social architecture of cell interactions," Biology Direct, vol. 1, article 32, 2006.

[13] T. Lee, "Stem cell therapy independent of stemness," World Journal of Stem Cells, vol. 4, no. 12, pp. 120-124, 2012.

[14] D. Javelaud and A. Mauviel, "Mammalian transforming growth factor- $\beta$ s: smad signaling and physio-pathological roles," International Journal of Biochemistry and Cell Biology, vol. 36, no. 7, pp. 1161-1165, 2004.

[15] R. I. Clark, K. J. Woodcock, F. Geissmann, C. Trouillet, and M. S. Dionne, "Multiple TGF- $\beta$ superfamily signals modulate the adult drosophila immune response," Current Biology, vol. 21, no. 19, pp. 1672-1677, 2011.

[16] K. W. Finnson, S. McLean, G. M. Di Guglielmo, and A. Philip, "Dynamics of transforming growth factor beta signaling in wound healing and scarring," Advances in Skin \& Wound Care, vol. 2, no. 5, pp. 195-214, 2013.

[17] J. W. Penn, A. O. Grobbelaar, and K. J. Rolfe, "The role of the TGF- $\beta$ family in wound healing, burns and scarring: a review," International Journal of Burns and Trauma, vol. 2, no. 1, pp. 1828, 2012.
[18] M. C. Fleisch, C. A. Maxwell, and M.-H. Barcellos-Hoff, "The pleiotropic roles of transforming growth factor beta in homeostasis and carcinogenesis of endocrine organs," EndocrineRelated Cancer, vol. 13, no. 2, pp. 379-400, 2006.

[19] V. Devescovi, E. Leonardi, G. Ciapetti, and E. Cenni, "Growth factors in bone repair," La Chirurgia degli Organi di Movimento, vol. 92, no. 3, pp. 161-168, 2008.

[20] S. A. Lehnert and R. J. Akhurst, "Embryonic expression pattern of TGF beta type-1 RNA suggests both paracrine and autocrine mechanisms of action," Development, vol. 104, no. 2, pp. 263273,1988

[21] A. Horner, P. Kemp, C. Summers et al., "Expression and distribution of transforming growth factor- $\beta$ isoforms and their signaling receptors in growing human bone," Bone, vol. 23, no. 2, pp. 95-102, 1998.

[22] A. Vortkamp, S. Pathi, G. M. Peretti, E. M. Caruso, D. J. Zaleske, and C. J. Tabin, "Recapitulation of signals regulating embryonic bone formation during postnatal growth and in fracture repair," Mechanisms of Development, vol. 71, no. 1-2, pp. 65-76, 1998.

[23] C. Ferguson, E. Alpern, T. Miclau, and J. A. Helms, "Does adult fracture repair recapitulate embryonic skeletal formation?" Mechanisms of Development, vol. 87, no. 1-2, pp. 57-66, 1999.

[24] G. L. Barnes, P. J. Kostenuik, L. C. Gerstenfeld, and T. A. Einhorn, "Growth factor regulation of fracture repair," Journal of Bone and Mineral Research, vol. 14, no. 11, pp. 1805-1815, 1999.

[25] B. Wildemann, G. Schmidmaier, S. Ordel, R. Stange, N. P. Haas, and M. Raschke, "Cell proliferation and differentiation during fracture healing are influenced by locally applied IGF-I and TGF-betal: comparison of two proliferation markers, PCNA and BrdU," Journal of Biomedical Materials Research Part B: Applied Biomaterials, vol. 65, no. 1, pp. 150-156, 2003.

[26] K. Sarahrudi, A. Thomas, M. Mousavi et al., "Elevated transforming growth factor-beta 1 (TGF- $\beta 1$ ) levels in human fracture healing," Injury, vol. 42, no. 8, pp. 833-837, 2011.

[27] P. V. Giannoudis, I. Pountos, J. Morley, S. Perry, H. I. Tarkin, and H.-C. Pape, "Growth factor release following femoral nailing," Bone, vol. 42, no. 4, pp. 751-757, 2008.

[28] M. E. Joyce, S. Jingushi, and M. E. Bolander, “Transforming growth factor- $\beta$ in the regulation of fracture repair," Orthopedic Clinics of North America, vol. 21, no. 1, pp. 199-209, 1990.

[29] E. Tsiridis, N. Upadhyay, and P. Giannoudis, "Molecular aspects of fracture healing: which are the important molecules?" Injury, vol. 38, no. 1, pp. S11-S25, 2007.

[30] J. E. de Larco and G. J. Todaro, "Growth factors from murine sarcoma virus-transformed cells," Proceedings of the National Academy of Sciences of the United States of America, vol. 75, no. 8, pp. 4001-4005, 1978.

[31] A. B. Roberts, M. A. Anzano, L. C. Lamb, J. M. Smith, and M. B. Sporn, "New class of transforming growth factors potentiated by epidermal growth factor: isolation from non-neoplastic tissues," Proceedings of the National Academy of Sciences of the United States of America, vol. 78, no. 9, pp. 5339-5343, 1981.

[32] M. A. Anzano, A. B. Roberts, C. A. Meyers et al., "Synergistic interaction of two classes of transforming growth factors from murine sarcoma cells," Cancer Research, vol. 42, no. 11, pp. 4776$4778,1982$.

[33] D. Fujii, J. E. Brissenden, R. Derynck, and U. Francke, “Transforming growth factor $\beta$ gene maps to human chromosome 19 long arm and to mouse chromosome 7," Somatic Cell and Molecular Genetics, vol. 12, no. 3, pp. 281-288, 1986. 
[34] D. E. Barton, B. E. Foellmer, J. Du, J. Tamm, R. Derynck, and U. Francke, "Chromosomal mapping of genes for transforming growth factors $\beta 2$ and $\beta 3$ in man and mouse: dispersion of TGF$\beta$ gene family," Oncogene Research, vol. 3, no. 4, pp. 323-331, 1988.

[35] P. Ten Dijke, A. H. M. Geurts van Kessel, J. G. Foulkes, and M. M. Le Beau, "Transforming growth factor type $\beta 3$ maps to human chromosome 14, region q23-q24," Oncogene, vol. 3, no. 6, pp. 721-724, 1988.

[36] H. Marquardt, M. N. Lioubin, and T. Ikeda, "Complete amino acid sequence of human transforming growth factor type $\beta 2$," Journal of Biological Chemistry, vol. 262, no. 25, pp. 12127-12131, 1987.

[37] J. Yue and K. M. Mulder, "Transforming growth factor- $\beta$ signal transduction in epithelial cells," Pharmacology and Therapeutics, vol. 91, no. 1, pp. 1-34, 2001.

[38] R. Cornelini, C. Rubini, M. Fioroni, G. A. Favero, R. Strocchi, and A. Piatteli, "Transforming growth factor-beta 1 expression in the peri-implant soft tissues of healthy and failing dental implants," Journal of Periodontology, vol. 74, no. 4, pp. 446-450, 2003.

[39] D. M. Kingsley, “The TGF- $\beta$ superfamily: new members, new receptors, and new genetic tests of function in different organisms," Genes \& Development, vol. 8, no. 2, pp. 133-146, 1994.

[40] R. Derynck, J. A. Jarrett, E. Y. Chen et al., "Human transforming growth factor- $\beta$ complementary DNA sequence and expression in normal and transformed cells," Nature, vol. 316, no. 6030, pp. 701-705, 1985.

[41] L. E. Gentry and B. W. Nash, "The pro domain of pre-protransforming growth factor beta 1 when independently expressed is a functional binding protein for the mature growth factor," Biochemistry, vol. 29, no. 29, pp. 6851-6857, 1990.

[42] L. E. Gentry, M. N. Lioubin, A. F. Purchio, and H. Marquardt, "Molecular events in the processing of recombinant type 1 prepro-transforming growth factor beta to the mature polypeptide," Molecular and Cellular Biology, vol. 8, no. 10, pp. 41624168, 1988.

[43] K. Janssens, P. Ten Dijke, S. H. Ralston, C. Bergmann, and W. van Hul, "Transforming growth factor- $\beta 1$ mutations in Camurati-Engelmann disease lead to increased signaling by altering either activation or secretion of the mutant protein," Journal of Biological Chemistry, vol. 278, no. 9, pp. 7718-7724, 2003.

[44] A. M. Brunner, H. Marquardt, A. R. Malacko, M. N. Lioubin, and A. F. Purchio, "Site-directed mutagenesis of cysteine residues in the pro region of the transforming growth factor $\beta 1$ precursor. Expression and characterization of mutant proteins," The Journal of Biological Chemistry, vol. 264, no. 23, pp. 1366013664, 1989.

[45] M. Kusakabe, P. L. Cheong, R. Nikfar, I. S. McLennan, and K. Koishi, "The structure of the TGF- $\beta$ latency associated peptide region determines the ability of the proprotein convertase furin to cleave TGF- $\beta$ s," Journal of Cellular Biochemistry, vol. 103, no. 1, pp. 311-320, 2008.

[46] C. M. Dubois, F. Blanchette, M.-H. Laprise, R. Leduc, F. Grondin, and N. G. Seidah, "Evidence that furin is an authentic transforming growth factor- $\beta 1$-converting enzyme," The American Journal of Pathology, vol. 158, no. 1, pp. 305-316, 2001.

[47] D. B. Rifkin, "Latent transforming growth factor- $\beta$ (TGF$\beta$ ) binding proteins: orchestrators of TGF- $\beta$ availability," The Journal of Biological Chemistry, vol. 280, no. 9, pp. 7409-7412, 2005.
[48] V. Todorovic, V. Jurukovski, Y. Chen, L. Fontana, B. Dabovic, and D. B. Rifkin, "Latent TGF- $\beta$ binding proteins," International Journal of Biochemistry and Cell Biology, vol. 37, no. 1, pp. 38-41, 2005.

[49] H. Hayashi and T. Sakai, "Biological significance of local TGF- $\beta$ activation in liver diseases," Frontiers in Physiology, vol. 3, article 12, 2012.

[50] J. Saharinen, J. Taipale, and J. Keski-Oja, "Association of the small latent transforming growth factor- $\beta$ with an eight cysteine repeat of its binding protein LTBP-1," The EMBO Journal, vol. 15, no. 2, pp. 245-253, 1996.

[51] J. Saharinen and J. Keski-Oja, "Specific sequence motif of 8-Cys repeats of TGF- $\beta$ binding proteins, LTBPs, creates a hydrophobic interaction surface for binding of small latent TGF- $\beta$," Molecular Biology of the Cell, vol. 11, no. 8, pp. 2691-2704, 2000.

[52] P.-E. Gleizes, R. C. Beavis, R. Mazzieri, B. Shen, and D. B. Rifkin, "Identification and characterization of an eight-cysteine repeat of the latent transforming growth factor- $\beta$ binding protein- 1 that mediates bonding to the latent transforming growth factor$\beta 1$," The Journal of Biological Chemistry, vol. 271, no. 47, pp. 29891-29896, 1996.

[53] Y. Chen, T. Ali, V. Todorovic, J. M. O’Leary, A. Kristina Downing, and D. B. Rifkin, "Amino acid requirements for formation of the TGF- $\beta$-latent TGF- $\beta$ binding protein complexes," Journal of Molecular Biology, vol. 345, no. 1, pp. 175-186, 2005.

[54] K. Miyazono, A. Olofsson, P. Colosetti, and C.-H. Heldin, "A role of the latent TGF- $\beta 1$-binding protein in the assembly and secretion of TGF- $\beta 1$," The EMBO Journal, vol. 10, no. 5, pp. 10911101, 1991.

[55] K. Miyazono, J. Thyberg, and C.-H. Heldin, "Retention of the transforming growth factor- $\beta 1$ precursor in the Golgi complex in a latent endoglycosidase H-sensitive form," Journal of Biological Chemistry, vol. 267, no. 8, pp. 5668-5675, 1992.

[56] S. S. Chaudhry, S. A. Cain, A. Morgan, S. L. Dallas, C. A. Shuttleworth, and C. M. Kielty, "Fibrillin-1 regulates the bioavailability of TGF $\beta 1$," The Journal of Cell Biology, vol. 176, no. 3, pp. 355-367, 2007.

[57] J. Taipale, K. Miyazono, C.-H. Heldin, and J. Keski-Oja, "Latent transforming growth factor- $\beta 1$ associates to fibroblast extracellular matrix via latent TGF- $\beta$ binding protein," The Journal of Cell Biology, vol. 124, no. 1-2, pp. 171-181, 1994.

[58] I. Nunes, P.-E. Gleizes, C. N. Metz, and D. B. Rifkin, "Latent transforming growth factor- $\beta$ binding protein domains involved in activation and transglutaminase-dependent crosslinking of latent transforming growth factor- $\beta$," The Journal of Cell Biology, vol. 136, no. 5, pp. 1151-1163, 1997.

[59] C. Unsöld, M. Hyytiäinen, L. Bruckner-Tuderman, and J. KeskiOja, "Latent TGF- $\beta$ binding protein LTBP-1 contains three potential extracellular matrix interacting domains," Journal of Cell Science, vol. 114, no. 1, pp. 187-197, 2001.

[60] Z. Isogai, R. N. Ono, S. Ushiro et al., "Latent transforming growth factor $\beta$-binding protein 1 interacts with fibrillin and is a microfibril-associated protein," The Journal of Biological Chemistry, vol. 278, no. 4, pp. 2750-2757, 2003.

[61] M. Horiguchi, M. Ota, and D. B. Rifkin, "Matrix control of transforming growth factor- $\beta$ function," Journal of Biochemistry, vol. 152, no. 4, pp. 321-329, 2012.

[62] I. D. Campbell and M. J. Humphries, "Integrin structure, activation, and interactions," Cold Spring Harbor Perspectives in Biology, vol. 3, no. 3, Article ID a004994, 2011. 
[63] J. A. Askari, P. A. Buckley, A. P. Mould, and M. J. Humphries, "Linking integrin conformation to function," Journal of Cell Science, vol. 122, no. 2, pp. 165-170, 2009.

[64] J. S. Munger and D. Sheppard, "Cross talk among TGF- $\beta$ signaling pathways, integrins, and the extracellular matrix," Cold Spring Harbor perspectives in biology, vol. 3, no. 11, Article ID a005017, 2011.

[65] J. S. Munger, X. Huang, H. Kawakatsu et al., "The integrin $\alpha \mathrm{v} \beta 6$ binds and activates latent TGF $\beta 1$ : a mechanism for regulating pulmonary inflammation and fibrosis," Cell, vol. 96, no. 3, pp. 319-328, 1999.

[66] J. P. Annes, Y. Chen, J. S. Munger, and D. B. Rifkin, "Integrin $\alpha \mathrm{v} \beta 6$-mediated activation of latent TGF- $\beta$ requires the latent TGF- $\beta$ binding protein-1," The Journal of Cell Biology, vol. 165, no. 5, pp. 723-734, 2004.

[67] P.-J. Wipff and B. Hinz, "Integrins and the activation of latent transforming growth factor $\beta 1$-an intimate relationship," European Journal of Cell Biology, vol. 87, no. 8-9, pp. 601-615, 2008.

[68] Y. Sato and D. B. Rifkin, "Inhibition of endothelial cell movement by pericytes and smooth muscle cells: activation of a latent transforming growth factor- $\beta 1$-like molecule by plasmin during co-culture," The Journal of Cell Biology, vol. 109, no. 1, pp. 309$315,1989$.

[69] Q. Yu and I. Stamenkovic, "Cell surface-localized matrix metalloproteinase-9 proteolytically activates TGF- $\beta$ and promotes tumor invasion and angiogenesis," Genes \& Development, vol. 14, no. 2, pp. 163-176, 2000.

[70] G. Ge and D. S. Greenspan, "BMP1 controls TGF $\beta 1$ activation via cleavage of latent TGF $\beta$-binding protein," The Journal of Cell Biology, vol. 175, no. 1, pp. 111-120, 2006.

[71] S. Schultz-Cherry, S. Ribeiro, L. Gentry, and J. E. MurphyUllrich, "Thrombospondin binds and activates the small and large forms of latent transforming growth factor- $\beta$ in a chemically defined system," Journal of Biological Chemistry, vol. 269, no. 43, pp. 26775-26782, 1994.

[72] S. Kojima, K. Nara, and D. B. Rifkin, "Requirement for transglutaminase in the activation of latent transforming growth factor$\beta$ in bovine endothelial cells," The Journal of Cell Biology, vol. 121, no. 2, pp. 439-448, 1993.

[73] R. Flaumenhaft, M. Abe, P. Mignatti, and D. B. Rifkin, "Basic fibroblast growth factor-induced activation of latent transforming growth factor $\beta$ in endothelial cells: regulation of plasminogen activator activity," The Journal of Cell Biology, vol. 118, no. 4, pp. 901-909, 1992.

[74] K. Koli, M. Myllärniemi, J. Keski-Oja, and V. L. Kinnula, "Transforming growth factor- $\beta$ activation in the lung: focus on fibrosis and reactive oxygen species," Antioxidants and Redox Signaling, vol. 10, no. 2, pp. 333-342, 2008.

[75] A. P. Hinck and M. D. O'Connor-McCourt, "Structures of TGF$\beta$ receptor complexes: implications for function and therapeutic intervention using ligand traps," Current Pharmaceutical Biotechnology, vol. 12, no. 12, pp. 2081-2098, 2011.

[76] S. Cheifetz, A. Bassols, K. Stanley, M. Ohta, J. Greenberger, and J. Massagué, "Heterodimeric transforming growth factor $\beta$. Biological properties and interaction with three types of cell surface receptors," The Journal of Biological Chemistry, vol. 263, no. 22, pp. 10783-10789, 1988.

[77] F. T. Boyd, S. Cheifetz, J. Andres, M. Laiho, and J. Massagué, "Transforming growth factor-beta receptors and binding proteoglycans," Journal of Cell Science. Supplement, vol. 13, pp. 131$138,1990$.
[78] T. Huang, L. David, V. Mendoza et al., "TGF- $\beta$ signalling is mediated by two autonomously functioning T $\beta$ RI:T $\beta$ RII pairs," The EMBO Journal, vol. 30, no. 7, pp. 1263-1276, 2011.

[79] T. Okadome, H. Yamashita, P. Franzén, A. Morén, C.-H. Heldin, and K. Miyazono, "Distinct roles of the intracellular domains of transforming growth factor- $\beta$ type I and type II receptors in signal transduction," The Journal of Biological Chemistry, vol. 269, no. 49, pp. 30753-30756, 1994.

[80] A. P. Hinck, "Structural studies of the TGF- $\beta$ s and their receptors-insights into evolution of the TGF- $\beta$ superfamily," FEBS Letters, vol. 586, no. 14, pp. 1860-1870, 2012.

[81] B. Pasche, Y. Luo, P. H. Rao et al., “Type I transforming growth factor $\beta$ receptor maps to $9 \mathrm{q} 22$ and exhibits a polymorphism and a rare variant within a polyalanine tract," Cancer Research, vol. 58, no. 13, pp. 2727-2732, 1998.

[82] F. T. Boyd and J. Massagué, “Transforming growth factor- $\beta$ inhibition of epithelial cell proliferation linked to the expression of a $53-\mathrm{kDa}$ membrane receptor," The Journal of Biological Chemistry, vol. 264, no. 4, pp. 2272-2278, 1989.

[83] K. E. Shapira, A. Gross, M. Ehrlich, and Y. I. Henis, "Coated pit-mediated endocytosis of the type I Transforming Growth Factor- $\beta$ (TGF- $\beta$ ) receptor depends on a Di-leucine family signal and is not required for signaling," The Journal of Biological Chemistry, vol. 287, no. 32, pp. 26876-26889, 2012.

[84] P. Franzén, P. ten Dijke, H. Ichijo et al., "Cloning of a TGF $\beta$ type I receptor that forms a heteromeric complex with the TGF $\beta$ type II receptor," Cell, vol. 75, no. 4, pp. 681-692, 1993.

[85] P. Franzén, C. H. Heldin, and K. Miyazono, “The GS domain of the transformining growth factor- $\beta$ type I receptor is important in signal transduction," Biochemical and Biophysical Research Communications, vol. 207, no. 2, pp. 682-689, 1995.

[86] H. Y. Lin, X.-F. Wang, E. Ng-Eaton, R. A. Weinberg, and H. F. Lodish, "Expression cloning of the TGF- $\beta$ type II receptor, a functional transmembrane serine/threonine kinase," Cell, vol. 68, no. 4, pp. 775-785, 1992.

[87] S. Mathew, V. V. V. S. Murty, S. Cheifetz, D. George, J. Massague, and R. S. K. Chaganti, "Transforming growth factor receptor gene TGFBR2 maps to human chromosome band 3p22," Genomics, vol. 20, no. 1, pp. 114-115, 1994.

[88] H. Liu, X. Wang, C. Wang et al., "Molecular cloning, in vitro expression and bioactivity of rabbit transforming growth factorbeta receptor type II (rTGF- $\beta$ RII)," Veterinary Immunology and Immunopathology, vol. 140, no. 1-2, pp. 55-62, 2011.

[89] K. Tsuchida, K. A. Lewis, L. S. Mathews, and W. W. Vale, "Molecular characterization of rat transforming growth factor$\beta$ type II receptor," Biochemical and Biophysical Research Communications, vol. 191, no. 3, pp. 790-795, 1993.

[90] J. L. Wrana, L. Attisano, J. Cárcamo et al., “TGF beta signals through a heteromeric protein kinase receptor complex," Cell, vol. 71, no. 6, pp. 1003-1014, 1992.

[91] J. L. Wrana, L. Attisano, R. Wieser, F. Ventura, and J. Massagué, "Mechanism of activation of the TGF- $\beta$ receptor," Nature, vol. 370, no. 6488, pp. 341-347, 1994.

[92] M. Saitoh, H. Nishitoh, T. Amagasa, K. Miyazono, M. Takagi, and H. Ichijo, "Identification of important regions in the cytoplasmic juxtamembrane domain of type I receptor that separate signaling pathways of transforming growth factor- $\beta$," The Journal of Biological Chemistry, vol. 271, no. 5, pp. 27692775, 1996. 
[93] K. Luo and H. F. Lodish, "Positive and negative regulation of type II TGF- $\beta$ receptor signal transduction by autophosphorylation on multiple serine residues," The EMBO Journal, vol. 16, no. 8, pp. 1970-1981, 1997.

[94] S. Cheifetz, J. L. Andres, and J. Massagué, "The transforming growth factor- $\beta$ receptor type III is a membrane proteoglycan. Domain structure of the receptor," The Journal of Biological Chemistry, vol. 263, no. 32, pp. 16984-16991, 1988.

[95] F. López-Casillas, H. M. Payne, J. L. Andres, and J. Massagué, "Betaglycan can act as a dual modulator of TGF- $\beta$ access to signaling receptors: mapping of ligand binding and GAG attachment sites," Journal of Cell Biology, vol. 124, no. 4, pp. 557-568, 1994.

[96] C. Bernabeu, J. M. Lopez-Novoa, and M. Quintanilla, "The emerging role of TGF- $\beta$ superfamily coreceptors in cancer," Biochimica et Biophysica Acta, vol. 1792, no. 10, pp. 954-973, 2009.

[97] J. Esparza-López, J. L. Montiel, M. M. Vilchis-Landeros, T. Okadome, K. Miyazono, and F. López-Casillas, "Ligand binding and functional properties of betaglycan, a co-receptor of the transforming growth factor- $\beta$ superfamily. Specialized binding regions for transforming growth factor- $\beta$ and inhibin $\mathrm{A}$," The Journal of Biological Chemistry, vol. 276, no. 18, pp. 14588-14596, 2001.

[98] M. Bilandzic and K. L. Stenvers, "Betaglycan: a multifunctional accessory," Molecular and Cellular Endocrinology, vol. 339, no. 1-2, pp. 180-189, 2011.

[99] F. Nassiri, M. D. Cusimano, B. W. Scheithauer et al., "Endoglin (CD105): a review of its role in angiogenesis and tumor diagnosis, progression and therapy," Anticancer Research, vol. 31, no. 6, pp. 2283-2290, 2011.

[100] S. Cheifetz, T. Bellón, C. Calés et al., "Endoglin is a component of the transforming growth factor- $\beta$ receptor system in human endothelial cells," The Journal of Biological Chemistry, vol. 267, no. 27, pp. 19027-19030, 1992.

[101] H. Yamashita, H. Ichijo, S. Grimsby, A. Morén, P. Ten Dijke, and K. Miyazono, "Endoglin forms a heteromeric complex with the signaling receptors for transforming growth factor- $\beta$," The Journal of Biological Chemistry, vol. 269, no. 3, pp. 1995-2001, 1994.

[102] E. J. Mitchell, L. Fitz-Gibbon, and M. D. O'Connor-McCourt, "Subtypes of betaglycan and of Type I and Type II transforming growth actor- $\beta$ (TGF- $\beta$ ) receptors with different affinities for TGF- $\beta 1$ and TGF- $\beta 2$ are exhibited by human placental trophoblast cells," Journal of Cellular Physiology, vol. 150, no. 2, pp. 334-343, 1992.

[103] P. Lönn, A. Morén, E. Raja, M. Dahl, and A. Moustakas, "Regulating the stability of TGF $\beta$ receptors and Smads," Cell Research, vol. 19, no. 1, pp. 21-35, 2009.

[104] S. Itoh, M. Landström, A. Hermansson et al., "Transforming growth factor $\beta 1$ induces nuclear export of inhibitory Smad7," Journal of Biological Chemistry, vol. 273, no. 44, pp. 2919529201, 1998.

[105] T. Ebisawa, M. Fukuchi, G. Murakami et al., "Smurf1 interacts with transforming growth factor- $\beta$ type I receptor through Smad7 and induces receptor degradation," The Journal of Biological Chemistry, vol. 276, no. 16, pp. 12477-12480, 2001.

[106] P. Kavsak, R. K. Rasmussen, C. G. Causing et al., "Smad7 binds to Smurf2 to form an E3 ubiquitin ligase that targets the TGF $\beta$ receptor for degradation," Molecular Cell, vol. 6, no. 6, pp. 13651375, 2000.
[107] X. Hao, Y. Wang, F. Ren et al., "SNX25 regulates TGF- $\beta$ signaling by enhancing the receptor degradation," Cellular Signalling, vol. 23, no. 5, pp. 935-946, 2011.

[108] Y. G. Chen, "Endocytic regulation of TGF-beta signaling," Cell Research, vol. 19, no. 1, pp. 58-70, 2009.

[109] C. le Roy and J. L. Wrana, "Clathrin- and non-clathrin-mediated endocytic regulation of cell signalling," Nature Reviews Molecular Cell Biology, vol. 6, no. 2, pp. 112-126, 2005.

[110] G. M. Di Guglielmo, C. Le Roy, A. F. Goodfellow, and J. L. Wrana, "Distinct endocytic pathways regulate TGF- $\beta$ receptor signalling and turnover," Nature Cell Biology, vol. 5, no. 5, pp. 410-421, 2003.

[111] G. J. Inman, "Linking Smads and transcriptional activation," The Biochemical Journal, vol. 386, no. 1, pp. e1-e3, 2005.

[112] A. Weiss and L. Attisano, "The TGFbeta superfamily signaling pathway," Wiley Interdisciplinary Reviews: Developmental Biology, vol. 2, no. 1, pp. 47-63, 2013.

[113] A. Moustakas and C.-H. Heldin, "The regulation of TGF $\beta$ signal transduction,” Development, vol. 136, no. 22, pp. 3699-3714, 2009.

[114] P. Makkar, R. P. R. Metpally, S. Sangadala, and B. V. B. Reddy, "Modeling and analysis of MH1 domain of Smads and their interaction with promoter DNA sequence motif," Journal of Molecular Graphics and Modelling, vol. 27, no. 7, pp. 803-812, 2009.

[115] J. Massagué, J. Seoane, and D. Wotton, "Smad transcription factors," Genes \& Development, vol. 19, no. 23, pp. 2783-2810, 2005.

[116] K. Tada, H. Inoue, T. Ebisawa et al., "Region between $\alpha$-helices 3 and 4 of the Mad homology 2 domain of Smad4: functional roles in oligomer formation and transcriptional activation," Genes to Cells, vol. 4, no. 12, pp. 731-741, 1999.

[117] J. Massagué, “TGF $\beta$ signalling in context,” Nature Reviews Molecular Cell Biology, vol. 13, no. 10, pp. 616-630, 2012.

[118] F. Itoh, N. Divecha, L. Brocks et al., "The FYVE domain in Smad anchor for receptor activation (SARA) is sufficient for localization of SARA in early endosomes and regulates TGF$\beta /$ Smad signalling," Genes to Cells, vol. 7, no. 3, pp. 321-331, 2002.

[119] Z. Xiao, X. Liu, Y. I. Henis, and H. F. Lodish, "A distinct nuclear localization signal in the $\mathrm{N}$ terminus of Smad 3 determines its ligand-induced nuclear translocation," Proceedings of the National Academy of Sciences of the United States of America, vol. 97, no. 14, pp. 7853-7858, 2000.

[120] Z. Xiao, X. Liu, and H. F. Lodish, "Importin $\beta$ mediates nuclear translocation of Smad 3," Journal of Biological Chemistry, vol. 275, no. 31, pp. 23425-23428, 2000.

[121] G. J. Inman, F. J. Nicolás, and C. S. Hill, "Nucleocytoplasmic shuttling of Smads 2, 3, and 4 permits sensing of TGF- $\beta$ receptor activity," Molecular Cell, vol. 10, no. 2, pp. 283-294, 2002.

[122] Y. Li, M. Wang, C. Carra, and F. A. Cucinotta, "Modularized Smad-regulated TGF $\beta$ signaling pathway," Mathematical Biosciences, vol. 240, no. 2, pp. 187-200, 2012.

[123] A. Hanyu, Y. Ishidou, T. Ebisawa, T. Shimanuki, T. Imamura, and K. Miyazono, "The N domain of Smad7 is essential for specific inhibition of transforming growth factor- $\beta$ signaling," The Journal of Cell Biology, vol. 155, no. 6, pp. 1017-1027, 2001.

[124] C. Suzuki, G. Murakami, M. Fukuchi et al., "Smurf1 regulates the inhibitory activity of Smad7 by targeting Smad7 to the plasma membrane," The Journal of Biological Chemistry, vol. 277, no. 42, pp. 39919-39925, 2002. 
[125] A. Moustakas and C. H. Heldin, "Non-Smad TGF- $\beta$ signals," Journal of Cell Science, vol. 118, no. 16, pp. 3573-3584, 2005.

[126] D. Horbelt, A. Denkis, and P. Knaus, "A portrait of Transforming Growth Factor $\beta$ superfamily signalling: background matters," International Journal of Biochemistry and Cell Biology, vol. 44, no. 3, pp. 469-474, 2012.

[127] A. V. Bakin, C. Rinehart, A. K. Tomlinson, and C. L. Arteaga, "p38 mitogen-activated protein kinase is required for TGF $\beta$ mediated fibroblastic transdifferentiation and cell migration," Journal of Cell Science, vol. 115, no. 15, pp. 3193-3206, 2002.

[128] D. A. Chapnick, L. Warner, J. Bernet, T. Rao, and X. Liu, "Partners in crime: The TGF $\beta$ and MAPK pathways in cancer progression," Cell and Bioscience, vol. 1, no. 1, article 42, 2011.

[129] Y. Cha, D.-K. Kim, J. Hyun, S.-J. Kim, and K.-S. Park, “TCEA3 binds to TGF-beta receptor I and induces Smad-independent, JNK-dependent apoptosis in ovarian cancer cells," Cellular Signalling, vol. 25, no. 5, pp. 1245-1251, 2013.

[130] D. Javelaud and A. Mauviel, "Crosstalk mechanisms between the mitogen-activated protein kinase pathways and Smad signaling downstream of TGF- $\beta$ : implications for carcinogenesis," Oncogene, vol. 24, no. 37, pp. 5742-5750, 2005.

[131] M. Hong, M. C. Wilkes, S. G. Penheiter, S. K. Gupta, M. Edens, and E. B. Leof, "Non-Smad transforming growth factor$\beta$ signaling regulated by focal adhesion kinase binding the $\mathrm{p} 85$ subunit of phosphatidylinositol 3-kinase," Journal of Biological Chemistry, vol. 286, no. 20, pp. 17841-17850, 2011.

[132] S. Lamouille, E. Connolly, J. W. Smyth, R. J. Akhurst, and R. Derynck, "TGF- $\beta$-induced activation of mTOR complex 2 drives epithelial-mesenchymal transition and cell invasion," Journal of Cell Science, vol. 125, part 5, pp. 1259-1273, 2012.

[133] A. Gingery, E. W. Bradley, L. Pederson, M. Ruan, N. J. Horwood, and M. J. Oursler, "TGF- $\beta$ coordinately activates TAK1/ MEK/AKT/NFkB and SMAD pathways to promote osteoclast survival," Experimental Cell Research, vol. 314, no. 15, pp. 27252738, 2008.

[134] J. Zhu, D. Nguyen, O. Hong, X.-H. Zhang, X.-M. Chen, and K. Zhang, "Inhibition of RhoA/Rho-kinase pathway suppresses the expression of extracellular matrix induced by CTGF or TGF- $\beta$ in ARPE-19," International Journal of Ophthalmology, vol. 6, no. 1, pp. 8-14, 2013.

[135] N. Rucci, "Molecular biology of bone remodelling," Clinical Cases in Mineral and Bone Metabolism, vol. 5, no. 1, pp. 49-56, 2008.

[136] G. Mori, P. D’Amelio, R. Faccio, and G. Brunetti, “The interplay between the bone and the immune system," Clinical and Developmental Immunology, vol. 2013, Article ID 720504, 16 pages, 2013.

[137] L. C. Gerstenfeld, D. M. Cullinane, G. L. Barnes, D. T. Graves, and T. A. Einhorn, "Fracture healing as a post-natal developmental process: molecular, spatial, and temporal aspects of its regulation," Journal of Cellular Biochemistry, vol. 88, no. 5, pp. 873-884, 2003.

[138] M. M. Sandberg, H. T. Aro, and E. I. Vuorio, "Gene expression during bone repair," Clinical Orthopaedics and Related Research, no. 289, pp. 292-312, 1993.

[139] C. H. Rundle, H. Wang, H. Yu et al., "Microarray analysis of gene expression during the inflammation and endochondral bone formation stages of rat femur fracture repair," Bone, vol. 38, no. 4, pp. 521-529, 2006.

[140] A. Schindeler, M. M. McDonald, P. Bokko, and D. G. Little, "Bone remodeling during fracture repair: the cellular picture,"
Seminars in Cell and Developmental Biology, vol. 19, no. 5, pp. 459-466, 2008.

[141] T. A. Einhorn and L. C. Gerstenfeld, "Fracture healing: mechanisms and interventions," Nature Reviews Rheumatology, 2014.

[142] P. V. Giannoudis, H. B. Tan, S. Perry, C. Tzioupis, and N. K. Kanakaris, "The systemic inflammatory response following femoral canal reaming using the reamer-irrigator-aspirator (RIA) device," Injury, vol. 41, no. 2, pp. S57-S61, 2010.

[143] L. Claes, S. Recknagel, and A. Ignatius, "Fracture healing under healthy and inflammatory conditions," Nature Reviews Rheumatology, vol. 8, no. 3, pp. 133-143, 2012.

[144] L. Marzona and B. Pavolini, "Play and players in bone fracture healing match," Clinical Cases in Mineral and Bone Metabolism, vol. 6, no. 2, pp. 159-162, 2009.

[145] D. E. Komatsu and S. J. Warden, “The control of fracture healing and its therapeutic targeting: improving upon nature," Journal of Cellular Biochemistry, vol. 109, no. 2, pp. 302-311, 2010.

[146] N. C. Keramaris, G. M. Calori, V. S. Nikolaou, E. H. Schemitsch, and P. V. Giannoudis, "Fracture vascularity and bone healing: a systematic review of the role of VEGF," Injury, vol. 39, supplement 2, pp. S45-S57, 2008.

[147] S. Graham, A. Leonidou, M. Lester, M. Heliotis, A. Mantalaris, and E. Tsiridis, "Investigating the role of PDGF as a potential drug therapy in bone formation and fracture healing," Expert Opinion on Investigational Drugs, vol. 18, no. 11, pp. 1633-1654, 2009.

[148] G. Schmidmaier, B. Wildemann, J. Heeger et al., "Improvement of fracture healing by systemic administration of growth hormone and local application of insulin-like growth factor-1 and transforming growth factor- $\beta 1$," Bone, vol. 31, no. 1, pp. 165-172, 2002.

[149] A. S. Patil, R. B. Sable, and R. M. Kothari, "An update on transforming growth factor- $\beta$ (TGF- $\beta$ ): sources, types, functions and clinical applicability for cartilage/bone healing," Journal of Cellular Physiology, vol. 226, no. 12, pp. 3094-3103, 2011.

[150] A. M. Phillips, "Overview of the fracture healing cascade," Injury, vol. 36, supplement 3, pp. S5-S7, 2005.

[151] R. E. Marx, E. R. Carlson, R. M. Eichstaedt, S. R. Schimmele, J. E. Strauss, and K. R. Georgeff, "Platelet-rich plasma: growth factor enhancement for bone grafts," Oral Surgery, Oral Medicine, Oral Pathology, Oral Radiology, and Endodontics, vol. 85, no. 6, pp. 638-646, 1998.

[152] M. E. Joyce, R. M. Terek, S. Jingushi, and M. E. Bolander, "Role of transforming growth factor- $\beta$ in fracture repair," Annals of the New York Academy of Sciences, vol. 593, pp. 107-123, 1990.

[153] W. T. Bourque, M. Gross, and B. K. Hall, "Expression of four growth factors during fracture repair," International Journal of Developmental Biology, vol. 37, no. 4, pp. 573-579, 1993.

[154] K. Matsumoto, S. Matsunaga, T. Imamura, Y. Ishidou, H. Yoshida, and T. Sakou, "Expression and distribution of transforming growth factor- $\beta$ and decorin during fracture healing," In Vivo, vol. 8, no. 2, pp. 215-220, 1994.

[155] X. Si, Y. Jin, L. Yang, G. L. Tipoe, and F. H. White, "Expression of BMP-2 and TGF- $\beta 1$ mRNA during healing of the rabbit mandible," European Journal of Oral Sciences, vol. 105, no. 4, pp. 325-330, 1997.

[156] T.-J. Cho, L. C. Gerstenfeld, and T. A. Einhorn, "Differential temporal expression of members of the transforming growth factor $\beta$ superfamily during murine fracture healing," Journal of Bone and Mineral Research, vol. 17, no. 3, pp. 513-520, 2002. 
[157] R. A. Meyer Jr., M. H. Meyer, M. Tenholder, S. Wondracek, R. Wasserman, and P. Garges, "Gene expression in older rats with delayed union of femoral fractures," Journal of Bone and Joint Surgery-Series A, vol. 85, no. 7, pp. 1243-1254, 2003.

[158] B. Wildemann, G. Schmidmaier, N. Brenner et al., "Quantification, localization, and expression of IGF-I and TGF- $\beta 1$ during growth factor-stimulated fracture healing," Calcified Tissue International, vol. 74, no. 4, pp. 388-397, 2004.

[159] J. G. Andrew, J. Hoyland, S. M. Andrew, A. J. Freemont, and D. Marsh, "Demonstration of TGF- $\beta 1$ mRNA by in situ hybridization in normal human fracture healing," Calcified Tissue International, vol. 52, no. 2, pp. 74-78, 1993.

[160] Y. Yu, J. L. Yang, P. J. Chapman-Sheath, and W. R. Walsh, “TGFbeta, BMPS, and their signal transducing mediators, Smads, in rat fracture healing," Journal of Biomedical Materials Research, vol. 60, no. 3, pp. 392-397, 2002.

[161] T. Sakou, T. Onishi, T. Yamamoto, T. Nagamine, T. K. Sampath, and P. Ten Dijke, "Localization of Smads, the TGF- $\beta$ family intracellular signaling components during endochondral ossification," Journal of Bone and Mineral Research, vol. 14, no. 7, pp. 1145-1152, 1999.

[162] G. Zimmermann, P. Henle, M. Küsswetter et al., "TGF- $\beta 1$ as a marker of delayed fracture healing," Bone, vol. 36, no. 5, pp. 779785, 2005.

[163] G. Zimmermann, A. Moghaddam, M. Reumann et al., "TGF- $\beta 1$ as a pathophysiological factor in fracture healing," Unfallchirurg, vol. 110, no. 2, pp. 130-136, 2007.

[164] A. Moghaddam, S. Weiss, C. G. Wölfl et al., "Cigarette smoking decreases TGF- $\beta 1$ serum concentrations after long bone fracture," Injury, vol. 41, no. 10, pp. 1020-1025, 2010.

[165] R. C. Castillo, M. J. Bosse, E. J. MacKenzie et al., "Impact of smoking on fracture healing and risk of complications in limb-threatening open tibia fractures," Journal of Orthopaedic Trauma, vol. 19, no. 3, pp. 151-157, 2005.

[166] G. Kaiser, A. Thomas, J. Köttstorfer, M. Kecht, and K. Sarahrudi, "Is the expression of transforming growth factor-betal after fracture of long bones solely influenced by the healing process?" International Orthopaedics, vol. 36, no. 10, pp. 2173-2179, 2012.

[167] H. Li, C.-Z. Liang, Y.-Q. Tao, C.-C. Shen, and Q.-X. Chen, "Elevated local TGF- $\beta 1$ level predisposes a closed bone fracture to tuberculosis infection," Medical Hypotheses, vol. 79, no. 3, pp. 400-402, 2012.

[168] G. Chen, C. Deng, and Y. P. Li, “TGF- $\beta$ and BMP signaling in osteoblast differentiation and bone formation," International Journal of Biological Sciences, vol. 8, no. 2, pp. 272-288, 2012.

[169] S. M. Seyedin, T. C. Thomas, A. Y. Thompson, D. M. Rosen, and K. A. Piez, "Purification and characterization of two cartilageinducing factors from bovine demineralized bone," Proceedings of the National Academy of Sciences of the United States of America, vol. 82, no. 8, pp. 2267-2271, 1985.

[170] R. K. Assoian, A. Komoriya, C. A. Meyers, D. M. Miller, and M. B. Sporn, "Transforming growth factor- $\beta$ in human platelets. Identification of a major storage site, purification, and characterization," The Journal of Biological Chemistry, vol. 258, no. 11, pp. 7155-7160, 1983.

[171] O. Wahlström, C. Linder, A. Kalén, and P. Magnusson, "Variation of $\mathrm{pH}$ in lysed platelet concentrates influence proliferation and alkaline phosphatase activity in human osteoblast-like cells," Platelets, vol. 18, no. 2, pp. 113-118, 2007.
[172] O. Wahlström, C. Linder, A. Kalén, and P. Magnusson, "Acidic preparations of platelet concentrates release bone morphogenetic protein-2," Acta Orthopaedica, vol. 79, no. 3, pp. 433-437, 2008.

[173] F. J. Hughes, J. E. Aubin, and J. N. M. Heersche, "Differential chemotactic responses of different populations of fetal rat calvaria cells to platelet-derived growth factor and transforming growth factor $\beta$," Bone and Mineral, vol. 19, no. 1, pp. 63-74, 1992.

[174] F. Celotti, A. Colciago, P. Negri-Cesi, A. Pravettoni, R. Zaninetti, and M. C. Sacchi, "Effect of platelet-rich plasma on migration and proliferation of SaOS-2 osteoblasts: role of platelet-derived growth factor and transforming growth factor- $\beta$,' Wound Repair and Regeneration, vol. 14, no. 2, pp. 195-202, 2006.

[175] J. S. Kim, J. G. Kim, M. Y. Moon et al., "Transforming growth factor- $\beta 1$ regulates macrophage migration via RhoA," Blood, vol. 108, no. 6, pp. 1821-1829, 2006.

[176] A. Mendelson, E. Frank, C. Allred et al., "Chondrogenesis by chemotactic homing of synovium, bone marrow, and adipose stem cells in vitro," The FASEB Journal, vol. 25, no. 10, pp. 34963504, 2011.

[177] K. Narine, O. De Wever, D. Van Valckenborgh et al., "Growth factor modulation of fibroblast proliferation, differentiation, and invasion: implications for tissue valve engineering," Tissue Engineering, vol. 12, no. 10, pp. 2707-2716, 2006.

[178] C. Chenu, J. Pfeilschifter, G. R. Mundy, and G. D. Roodman, "Transforming growth factor $\beta$ inhibits formation of osteoclastlike cells in long-term human marrow cultures," Proceedings of the National Academy of Sciences of the United States of America, vol. 85, no. 15, pp. 5683-5687, 1988.

[179] J. Pfeilschifter, S. M. Seyedin, and G. R. Mundy, "Transforming growth factor beta inhibits bone resorption in fetal rat long bone cultures," The Journal of Clinical Investigation, vol. 82, no. 2, pp. 680-685, 1988.

[180] A. Erlebacher, E. H. Filvaroff, J.-Q. Ye, and R. Derynck, "Osteoblastic responses to TGF- $\beta$ during bone remodeling," Molecular Biology of the Cell, vol. 9, no. 7, pp. 1903-1918, 1998.

[181] G. R. Mundy, "Regulation of bone formation by bone morphogenetic proteins and other growth factors," Clinical Orthopaedics and Related Research, no. 324, pp. 24-28, 1996.

[182] T.-F. Li, R. J. O'Keefe, and D. Chen, “TGF-beta signaling in chondrocytes," Frontiers in Bioscience, vol. 10, pp. 681-688, 2005.

[183] L. F. Bonewald and S. L. Dallas, "Role of active and latent transforming growth Factor $\beta$ in bone formation," Journal of Cellular Biochemistry, vol. 55, no. 3, pp. 350-357, 1994.

[184] M. Centrella, M. C. Horowitz, J. M. Wozney, and T. L. Mccarthy, "Transforming growth factor- $\beta$ gene family members and bone," Endocrine Reviews, vol. 15, no. 1, pp. 27-39, 1994.

[185] M. Noda, "Transcriptional regulation of osteocalcin production by transforming growth factor- $\beta$ in rat osteoblast-like cells," Endocrinology, vol. 124, no. 2, pp. 612-617, 1989.

[186] J. Massagué, "The transforming growth factor-beta family," Annual Review of Cell Biology, vol. 6, pp. 597-641, 1990.

[187] P. B. Saadeh, B. J. Mehrara, D. S. Steinbrech et al., "Transforming growth factor- $\beta 1$ modulates the expression of vascular endothelial growth factor by osteoblasts," American Journal of Physiology, vol. 277, no. 4, part 1, pp. C628-C637, 1999.

[188] C. C. Chua, R. C. Hamdy, and B. H. L. Chua, "Mechanism of transforming growth factor- $\beta 1$-induced expression of vascular endothelial growth factor in murine osteoblastic MC3T3-E1 cells," Biochimica et Biophysica Act-Molecular Cell Research, vol. 1497, no. 1, pp. 69-76, 2000. 
[189] Y. Yamada, T. Tamura, K. Hariu, Y. Asano, S. Sato, and K. Ito, "Angiogenesis in newly augmented bone observed in rabbit calvarium using a titanium cap," Clinical Oral Implants Research, vol. 19, no. 10, pp. 1003-1009, 2008.

[190] M. L. Brandi and P. Collin-Osdoby, "Vascular biology and the skeleton," Journal of Bone and Mineral Research, vol. 21, no. 2, pp. 183-192, 2006.

[191] P. Madeddu, "Therapeutic angiogenesis and vasculogenesis for tissue regeneration," Experimental Physiology, vol. 90, no. 3, pp. 315-326, 2005.

[192] V. V. Orlova, Z. Liu, M.-J. Goumans, and P. ten Dijke, “Controlling angiogenesis by two unique TGF- $\beta$ type I receptor signaling pathways," Histology and Histopathology, vol. 26, no. 9, pp. 12191230, 2011.

[193] G. Ferrari, B. D. Cook, V. Terushkin, G. Pintucci, and P. Mignatti, "Transforming growth factor-beta 1 (TGF- $\beta 1$ ) induces angiogenesis through vascular endothelial growth factor (VEGF)-mediated apoptosis," Journal of Cellular Physiology, vol. 219, no. 2, pp. 449-458, 2009.

[194] M. T. Coconi, B. Nico, P. Rebuffat et al., "Angiogenic response induced by acellular femoral matrix in vivo," Journal of Anatomy, vol. 207, no. 1, pp. 79-83, 2005.

[195] M. E. Joyce, A. B. Roberts, M. B. Sporn, and M. E. Bolander, "Transforming growth factor- $\beta$ and the initiation of chondrogenesis and osteogenesis in the rat femur," Journal of Cell Biology, vol. 110, no. 6, pp. 2195-2207, 1990.

[196] Y. Sun, Y. Lu, Y. Hu, F. Ma, and W. Chen, "Induction of osteogenesis by bovine platelet transforming growth factor-beta (TGF- $\beta$ ) in adult mouse femur," Chinese Medical Journal, vol. 108, no. 12, pp. 914-918, 1995.

[197] L. S. Beck, E. P. Amento, Y. Xu et al., “TGF- $\beta 1$ induces bone closure of skull defects: temporal dynamics of bone formation in defects exposed to rhTGF- $\beta 1$," Journal of Bone and Mineral Research, vol. 8, no. 6, pp. 753-761, 1993.

[198] M. Lind, B. Schumacker, K. Søballe, J. Keller, F. Melsen, and C. Bünger, "Transforming growth factor- $\beta$ enhances fracture healing in rabbit tibiae," Acta Orthopaedica Scandinavica, vol. 64, no. 5, pp. 553-556, 1993.

[199] H. M. Nielsen, T. T. Andreassen, T. Ledet, and H. Oxlund, "Local injection of TGF- $\beta$ increases the strength of tibial fractures in the rat," Acta Orthopaedica Scandinavica, vol. 65, no. 1, pp. 3741, 1994.

[200] M. A. Critchlow, Y. S. Bland, and D. E. Ashhurst, "The effect of exogenous transforming growth factor- $\beta 2$ on healing fractures in the rabbit," Bone, vol. 16, no. 5, pp. 521-527, 1995.

[201] J. D. Heckman, W. Ehler, B. P. Brooks et al., "Bone morphogenetic protein but not transforming growth factor- $\beta$ enhances bone formation in canine diaphyseal nonunions implanted with a biodegradable composite polymer," Journal of Bone and Joint Surgery, Series A, vol. 81, no. 12, pp. 1717-1729, 1999.

[202] G. Schmidmaier, M. Lucke, P. Schwabe, M. Raschke, N. P. Haas, and B. Wildemann, "Collective review: bioactive implants coated with poly(D,L-lactide) and growth factors IGF-I, TGF$\beta 1$, or BMP-2 for stimulation of fracture healing," Journal of Long-Term Effects of Medical Implants, vol. 16, no. 1, pp. 61-69, 2006.

[203] G. Schmidmaier, B. Wildemann, T. Gäbelein et al., "Synergistic effect of IGF-I and TGF- $\beta 1$ on fracture healing in rats: single versus combined application of IGF-I and TGF- $\beta 1$," Acta Orthopaedica Scandinavica, vol. 74, no. 5, pp. 604-610, 2003.

[204] G. Schmidmaier, B. Wildemann, M. Lübberstedt, N. P. Haas, and M. Raschke, "IGF-I and TGF-beta 1 incorporated in a
poly(D,L-lactide) implant coating stimulates osteoblast differentiation and collagen-1 production but reduces osteoblast proliferation in cell culture," Journal of Biomedical Materials Research Part B Applied Biomaterials, vol. 65, no. 1, pp. 157-162, 2003.

[205] A. Bernstein, H. O. Mayr, and R. Hube, "Can bone healing in distraction osteogenesis be accelerated by local application of IGF-1 and TGF-betal?" Journal of Biomedical Materials Research Part B: Applied Biomaterials, vol. 92, no. 1, pp. 215-225, 2010.

[206] S. Srouji, A. Rachmiel, I. Blumenfeld, and E. Livne, "Mandibular defect repair by TGF- $\beta$ and IGF-1 released from a biodegradable osteoconductive hydrogel," Journal of Cranio-Maxillofacial Surgery, vol. 33, no. 2, pp. 79-84, 2005.

[207] A. Lamberg, G. Schmidmaier, K. Søballe, and B. Elmengaard, "Locally delivered TGF- $\beta 1$ and IGF-1 enhance the fixation of titanium implants: a study in dogs," Acta Orthopaedica, vol. 77, no. 5, pp. 799-805, 2006.

[208] T. T. Gui, J. Pagkalos, E. Tsiridis, A. A. Narvani, M. Heliotis, and A. Mantalaris, "Growth hormone: does it have a therapeutic role in fracture healing?" Expert Opinion on Investigational Drugs, vol. 18, no. 7, pp. 887-911, 2009.

[209] T. J. Myers, Y. Yan, F. Granero-Molto et al., "Systemically delivered insulin-like growth factor-I enhances mesenchymal stem cell-dependent fracture healing," Growth Factors, vol. 30, no. 4, pp. 230-241, 2012.

[210] X. L. Griffin, C. M. Smith, and M. L. Costa, "The clinical use of platelet-rich plasma in the promotion of bone healing: a systematic review," Injury, vol. 40, no. 2, pp. 158-162, 2009.

[211] X. L. Griffin, D. Wallace, N. Parsons, and M. L. Costa, "Platelet rich therapies for long bone healing in adults," Cochrane Database of Systematic Reviews, vol. 7, Article ID CD009496, 2012.

[212] M. Lenza, S. de Barros Ferraz, D. C. M. Viola, O. F. P. dos Santos, M. C. Neto, and M. Ferretti, "Platelet-rich plasma for long bone healing," Einstein, vol. 11, no. 1, pp. 122-127, 2013.

[213] R. S. Dhillon, E. M. Schwarz, and M. D. Maloney, "Plateletrich plasma therapy-future or trend?" Arthritis Research \& Therapy, vol. 14, no. 4, p. 219, 2012.

[214] D. Dallari, L. Savarino, C. Stagni et al., "Enhanced tibial osteotomy healing with use of bone grafts supplemented with platelet gel or platelet gel and bone marrow stromal cells," Journal of Bone and Joint Surgery A, vol. 89, no. 11, pp. 24132420, 2007.

[215] J. C. Peerbooms, J. W. Colaris, A. A. Hakkert et al., "No positive bone healing after using platelet rich plasma in a skeletal defect. An observational prospective cohort study," International Orthopaedics, vol. 36, no. 10, pp. 2113-2119, 2012.

[216] H. Kitoh, T. Kitakoji, H. Tsuchiya, M. Katoh, and N. Ishiguro, "Transplantation of culture expanded bone marrow cells and platelet rich plasma in distraction osteogenesis of the long bones," Bone, vol. 40, no. 2, pp. 522-528, 2007.

[217] H. Kitoh, T. Kitakoji, H. Tsuchiya, M. Katoh, and N. Ishiguro, "Distraction osteogenesis of the lower extremity in patients with achondroplasia/hypochondroplasia treated with transplantation of culture-expanded bone marrow cells and platelet-rich plasma," Journal of Pediatric Orthopaedics, vol. 27, no. 6, pp. 629-634, 2007.

[218] L. Y. Carreon, S. D. Glassman, Y. Anekstein, and R. M. Puno, "Platelet gel (AGF) fails to increase fusion rates in instrumented posterolateral fusions," Spine, vol. 30, no. 9, pp. E243-E247, 2005. 
[219] G. M. Calori, M. D’Avino, L. Tagliabue, W. Albisetti, M. d'Imporzano, and G. Peretti, "An ongoing research for evaluation of treatment with BMPs or AGFs in long bone non-union: protocol description and preliminary results," Injury, vol. 37, supplement 3, pp. S43-S50, 2006.

[220] C. Bibbo, C. M. Bono, and S. S. Lin, "Union rates using autologous platelet concentrate alone and with bone graft in high-risk foot and ankle surgery patients," Journal of Surgical Orthopaedic Advances, vol. 14, no. 1, pp. 17-22, 2005.

[221] C.-L. Shen, I.-S. Kwun, S. Wang et al., "Functions and mechanisms of green tea catechins in regulating bone remodeling," Current Drug Targets, vol. 14, no. 13, pp. 1619-1630, 2013.

[222] J. A. Kanis, E. V. McCloskey, H. Johansson, and A. Oden, "Approaches to the targeting of treatment for osteoporosis," Nature reviews. Rheumatology, vol. 5, no. 8, pp. 425-431, 2009.

[223] V. S. Nikolaou, N. Efstathopoulos, G. Kontakis, N. K. Kanakaris, and P. V. Giannoudis, "The influence of osteoporosis in femoral fracture healing time," Injury, vol. 40, no. 6, pp. 663-668, 2009.

[224] S. H. Ralston, "Genetics of osteoporosis," Proceedings of the Nutrition Society, vol. 66, no. 2, pp. 158-165, 2007.

[225] F. Bertoldo, L. D'agruma, F. Furlan et al., "Transforming growth factor- $\beta 1$ gene polymorphism, bone turnover, and bone mass in Italian postmenopausal women," Journal of Bone and Mineral Research, vol. 15, no. 4, pp. 634-639, 2000.

[226] Y. Yamada, A. Miyauchi, Y. Takagi et al., "Association of a polymorphism of the transforming growth factor beta-1 gene with prevalent vertebral fractures in Japanese women," The American Journal of Medicine, vol. 109, no. 3, pp. 244-247, 2000.

[227] Y. Yamada, A. Miyauchi, Y. Takagi, M. Tanaka, M. Mizuno, and A. Harada, "Association of the $\mathrm{C}-509 \rightarrow \mathrm{T}$ polymorphism, alone or in combination with the T869 $\rightarrow \mathrm{C}$ polymorphism, of the transforming growth factor- $\beta 1$ gene with bone mineral density and genetic susceptibility to osteoporosis in Japanese women," Journal of Molecular Medicine, vol. 79, no. 2, pp. 149-156, 2001.

[228] V. Hinke, T. Seck, C. Clanget, C. Scheidt-Nave, R. Ziegler, and J. Pfeilschifter, "Association of transforming growth factor$\beta 1(\mathrm{TGF} \beta 1) \mathrm{T} 29 \rightarrow \mathrm{C}$ gene polymorphism with bone mineral density (BMD), changes in BMD, and serum concentrations of TGF- $\beta 1$ in a population-based sample of postmenopausal German women," Calcified Tissue International, vol. 69, no. 6, pp. 315-320, 2001.

[229] D. Utennam, A. Tungtrongchitr, B. Phonrat, R. Tungtrongchitr, and S. Preutthipan, "Association of T869C gene polymorphism of transforming growth factor- $\beta 1$ with low protein levels and anthropometric indices in osteopenia/osteoporosis postmenopausal Thai women," Genetics and Molecular Research, vol. 11, no. 1, pp. 87-99, 2012.

[230] B. L. Langdahl, A. G. Uitterlinden, S. H. Ralston et al., "Largescale analysis of association between polymorphisms in the transforming growth factor beta 1 gene (TGFB1) and osteoporosis: the GENOMOS study," Bone, vol. 42, no. 5, pp. 969-981, 2008.

[231] J. Massagué, "TGFbeta in cancer," Cell, vol. 134, no. 2, pp. 215230, 2008.

[232] E. C. Connolly, J. Freimuth, and R. J. Akhurst, "Complexities of TGF- $\beta$ targeted cancer therapy," International Journal of Biological Sciences, vol. 8, no. 7, pp. 964-978, 2012.

[233] S. H. Wrzesinski, Y. Y. Wan, and R. A. Flavell, “Transforming growth factor- $\beta$ and the immune response: implications for anticancer therapy," Clinical Cancer Research, vol. 13, no. 18, pp. 5262-5270, 2007.
[234] M. Gigante, L. Gesualdo, and E. Ranieri, "TGF-beta: a master switch in tumor immunity," Current Pharmaceutical Design, vol. 18, no. 27, pp. 4126-4134, 2012.

[235] F. Itoh, T. Watabe, and K. Miyazono, "Roles of TGF- $\beta$ family signals in the fate determination of pluripotent stem cells," Seminars in Cell \& Developmental Biology, vol. 32, pp. 98-106, 2014.

[236] J. K. Venkatesan, A. Rey-Rico, G. Schmitt, A. Wezel, H. Madry, and M. Cucchiarini, "rAAV-mediated overexpression of TGF$\beta$ stably restructures human osteoarthritic articular cartilage in situ," Journal of Translational Medicine, vol. 11, article 211, 2013.

[237] S. Acharjee, T.-K. Chung, S. Gopinadhan et al., "Sharp-1 regulates TGF- $\beta$ signaling and skeletal muscle regeneration," Journal of Cell Science, vol. 127, no. 3, pp. 599-608, 2014.

[238] J. Liu, K. Johnson, J. Li et al., "Regenerative phenotype in mice with a point mutation in transforming growth factor $\beta$ type I receptor (TGFBR1)," Proceedings of the National Academy of Sciences of the United States of America, vol. 108, no. 35, pp. 1456014565, 2011.

[239] F. Nasseri, G. A. Gholami, and M. Kadkhodazadeh, "Effect of bioactive ceramic and recombinant human transforming growth factor-beta (rhTGF-beta) on regeneration of parietal bone defects in rat," Journal of Long-Term Effects of Medical Implants, vol. 21, no. 1, pp. 71-78, 2011. 


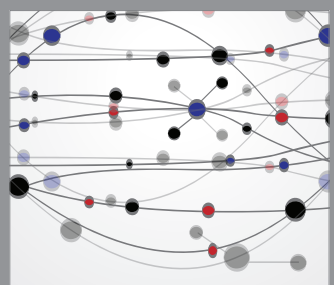

The Scientific World Journal
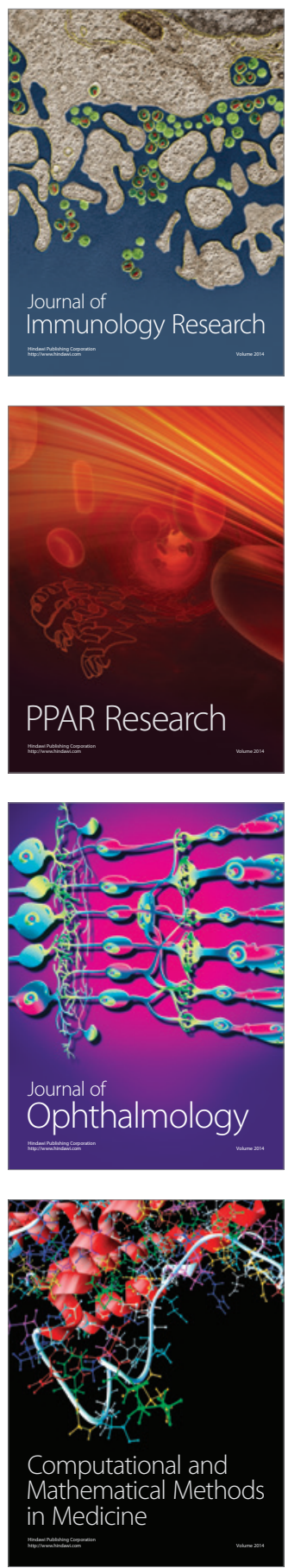

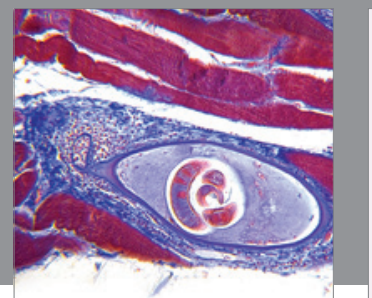

Gastroenterology

Research and Practice
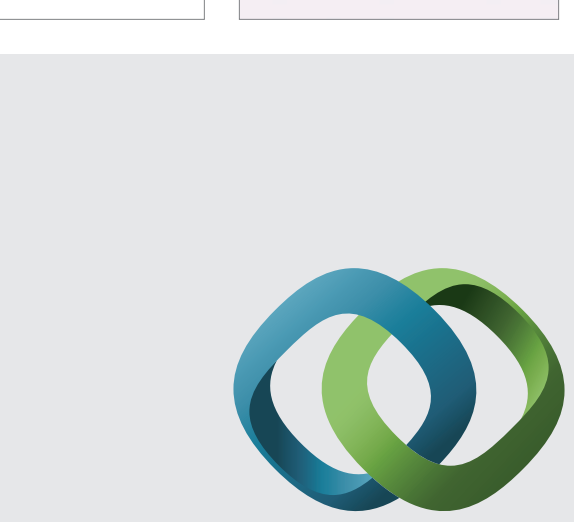

\section{Hindawi}

Submit your manuscripts at

http://www.hindawi.com
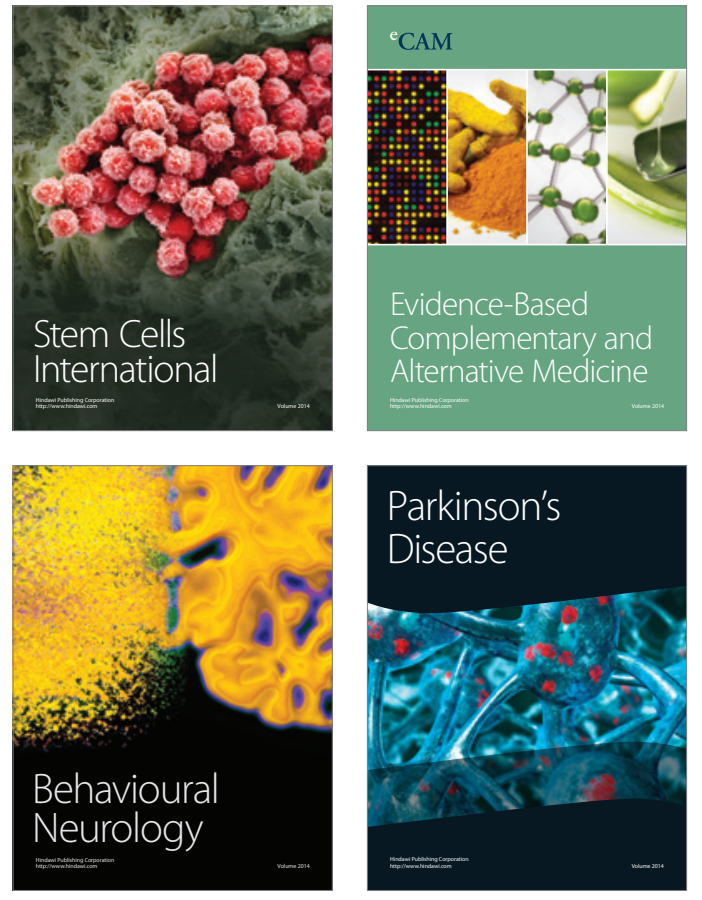
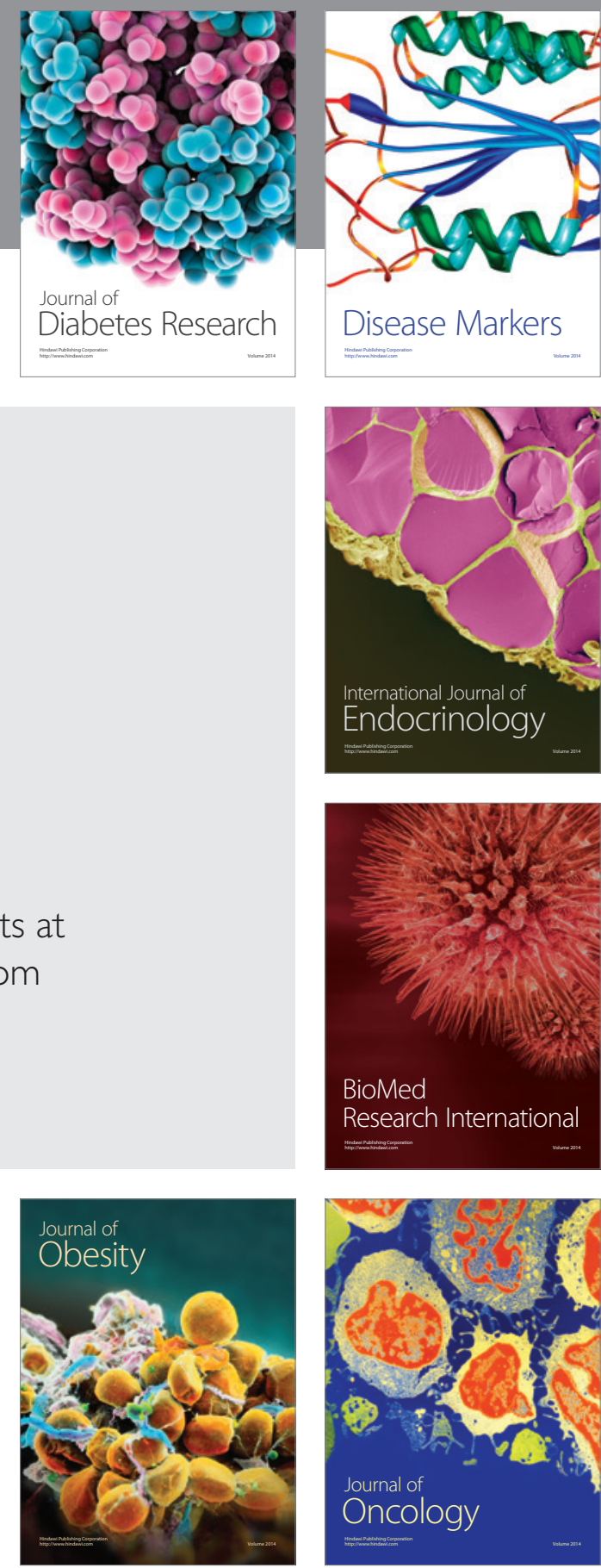

Disease Markers
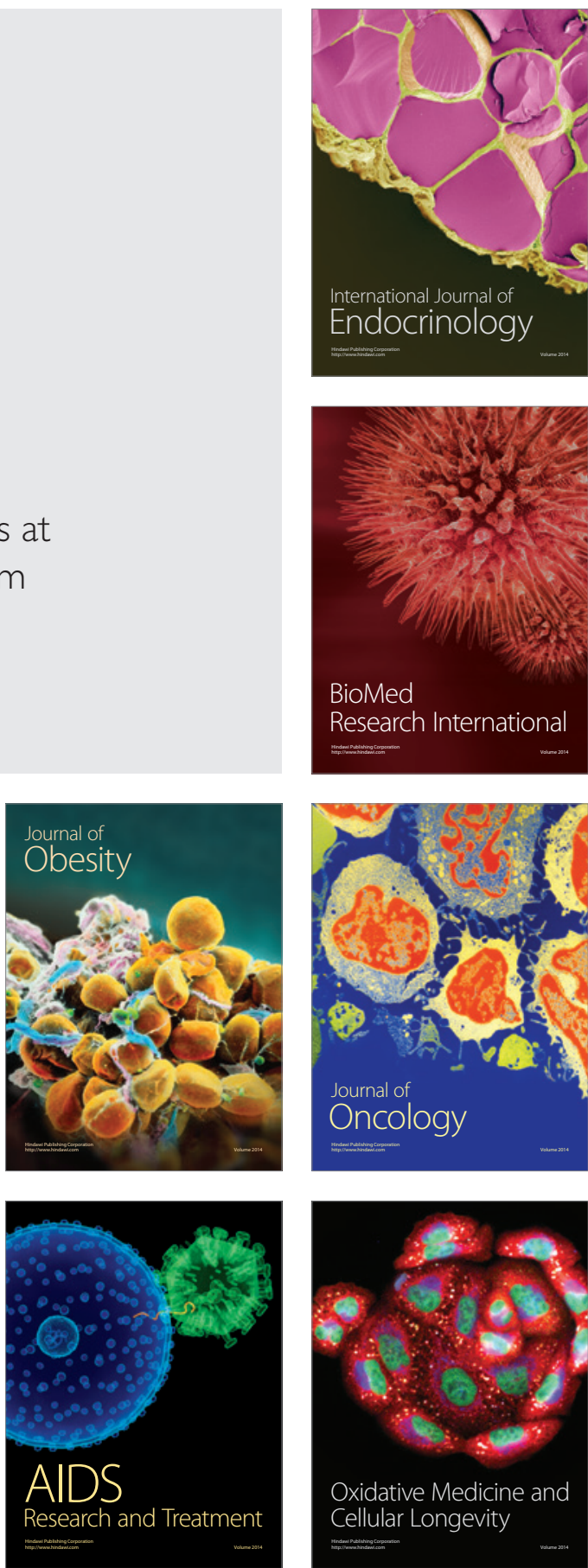